PRACE GEOGRAFICZNE

zeszyt $148,2017,81-106$

doi: 10.4467/20833113PG.17.004.6272

Instytut Geografii i Gospodarki Przestrzennej UJ

Wydawnictwo Uniwersytetu Jagiellońskiego

\title{
SKŁAD CHEMICZNY WÓD POTOKÓW POŁUDNIOWEGO STOKU MASYWU BABIEJ GÓRY
}

\author{
Matgoræata Malata, Jacek Motyka, Adam Postawa
}

\section{Water chemistry of streams on the south slope Babia Góra Mt}

Abstract: The chemical composition of the waters of mountain streams depends on natural and anthropogenic conditions. The aim of the study was to determine the variability of physico-chemical properties of water in the streams in the massif of Babia Góra. The study selected fourteen streams located in the Babia Góra National Park and its buffer zone. Based on the results of analyses of macronutrients and micronutrients of ions, conditions determining the physico-chemical parameters of water were determined. The physical and chemical composition of stream waters proved to be conditioned by the geology of catchments, the process of dilution, water temperature and the type of plant communities as well as and the seasonality of vegetation.

Keywords: physical and chemical parameters of water, mountain streams, variability in time-space, Babiogórski National Park

Zarys treści: Skład chemiczny wód potoków górskich zależy od uwarunkowań naturalnych i antropogenicznych. Celem opracowania jest określenie zmienności cech fizykochemicznych wód potoków w masywie Babiej Góry. Do badań wybrano 14 potoków położonych w Babiogórskim Parku Narodowym oraz w jego otulinie. Na podstawie wyników analiz makroskładników oraz mikroskładników wybranych jonów określono uwarunkowania determinujące parametry fizykochemiczne wód. Znaczenie dla składu fizykochemicznego wód potoków wykazała budowa geologiczna zlewni potoków, proces rozcieńczania, temperatura wody oraz typ zbiorowisk roślinnych i ich sezonowość wegetacji.

Stowa kluczowe: parametry fizykochemiczne wód, potoki górskie, zmienność czasowa i przestrzenna, Babiogórski Park Narodowy 


\section{Wprowadzenie}

Właściwości fizykochemiczne wód potoków zależą od uwarunkowań naturalnych, które pod wpływem antropopresji ulegają modyfikacji (Chełmicki 2001). Do głównych uwarunkowań naturalnych można zaliczyć: rodzaj skał, wykształcenie i rodzaj gleb, warunki klimatyczne, rzeźbę terenu oraz roślinność (Żelazny i in. 2009, 2013; Wolanin 2013). Na obszarach górskich oddziaływanie człowieka na skład fizykochemiczny wód następuje poprzez zanieczyszczone opady atmosferyczne (Małecka 1991; Małecka i in. 2007; Kurzyca i in. 2009) oraz turystykę górską, m.in. zrzuty ścieków ze schronisk górskich (Siwek i in. 2009), w przeciwieństwie do obszarów nizinnych, gdzie przyczyn ognisk zanieczyszczeń może być więcej. Dopływ zanieczyszczeń przejawia się przede wszystkim obecnością w wodzie podwyższonych stężeń związków biogennych, tj. azotanów, chlorków, fosforanów oraz siarczanów (Wolanin 2013). Babia Góra - mimo że objęta jest ochroną prawną (Babiogórski Park Narodowy, Rezerwat Biosfery UNESCO, Obszar Natura 2000) - podlega silnej antropopresji ze względu na intensywny ruch turystyczny. Badania składu fizykochemicznego wód źródeł i potoków babiogórskich prowadzili między innymi: Łajczak (1983, 1998, 2004), Pasternak (1983), Postawa (2005), Malata (2014, 2015), Malata i Motyka (2015). Ich badania wskazują na występowanie zależności między uwarunkowaniami naturalnymi, odziaływaniem człowieka a cechami fizycznymi i chemicznymi wód źródeł i potoków.

Celem niniejszego opracowania jest rozpoznanie źródeł dostawy składników chemicznych, zmienność czasowa i przestrzenna parametrów fizykochemicznych wód potoków oraz określenie aktualnego poziomu antropopresji. Próbki wody pobrano z 14 głównych potoków (ryc. 1) z południowej części masywu Babiej Góry - w obrębie Babiogórskiego Parku Narodowego (BgPN) oraz otuliny Parku.

\section{Charakterystyka obszaru badań}

Teren badań położony jest w południowej części BgPN oraz w otulinie na wysokości od 800 m n.p.m. do 1100 m n.p.m. (ryc. 1). Obszar ten zalicza się do Karpat Zewnętrznych, Beskidu Zachodniego, wschodniej części Beskidu Żywieckiego (Kondracki 2002). Najwyższym punktem w masywie Babiej Góry jest Diablak 1725 m n.p.m. (Łajczak 2004). Masyw Babiej Góry administracyjnie leży na granicy Polski i Słowacji. Teren badań znajduje się w całości w granicach Polski, w województwie małopolskim, powiecie nowotarskim oraz w dwóch gminach: Jabłonka oraz Lipnica Wielka. Głównym grzbietem masywu Babiej Góry biegnie Europejski Dział Wodny, między zlewiskami Bałtyku i Morza Czarnego (Postawa 2005). Potoki spływające po stoku południowym należą do zlewni Czarnej Orawy i Białej Orawy, 


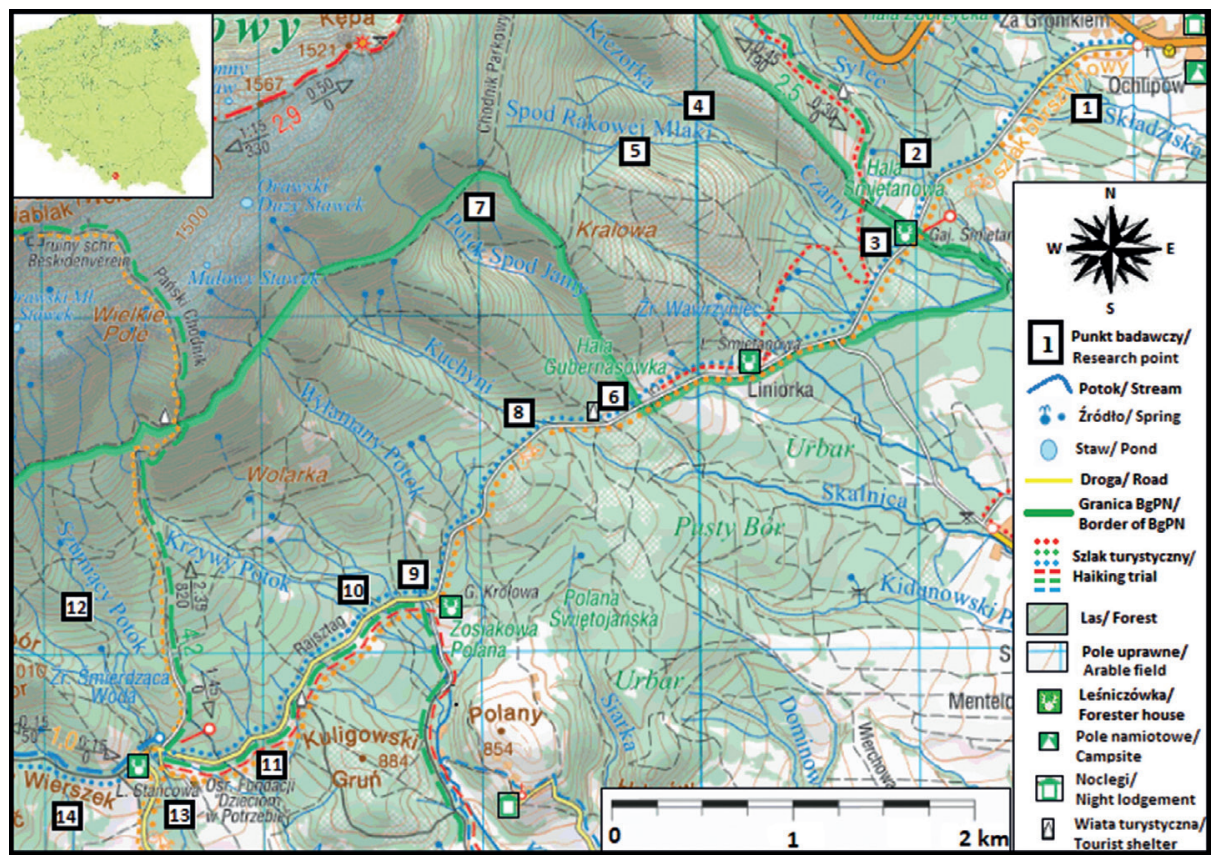

Rys. 1. Lokalizacja stanowisk badawczych w BgPN i jego otulinie:

1 - Składziska (800 m n.p.m.), 2 - Sylec (820 m n.p.m.), 3 - Czarny (820 m n.p.m.), 4 - Kiczorka (1000 m n.p.m.), 5 - Spod Rakowej Młaki (1100 m n.p.m.), 6 - Spod Jamy (900 m n.p.m.), 7-Jamy (1100 m n.p.m.), 8-Kuchyni (920 m n.p.m.), 9-Wyłamany (860 m n.p.m.), 10 - Krzywy (880 m n.p.m.), 11 - Młynkówka (860 m n.p.m.), 12 - Szumiący (1000 m n.p.m.), 13 - Lipniczanka (880 m n.p.m.) oraz 14 - Przywarówka (880 m n.p.m.).

Fig. 1. Water sampling sites in the BPN and lagging national park:

1 - Składziska (800 m a.s.l.), 2 - Sylec (820 m a.s.l.), 3 - Czarny (820 m a.s.l.), 4 - Kiczorka (1000 m a.s.l.), 5 - Spod Rakowej Młaki (1100 m a.s.l.), 6 - Spod Jamy (900 m a.s.l.), 7 - Jamy (1100 m a.s.1.), 8 - Kuchyni (920 m a.s.1.), 9 - Wyłamany (860 m a.s.l.), 10 - Krzywy (880 m a.s.l.), 11 - Młynkówka (860 m a.s.l.), 12 - Szumiący (1000 m a.s.l.), 13 - Lipniczanka (880 m a.s.1.) oraz 14 - Przywarówka (880 m a.s.1.). 
które oddają wody poprzez Orawę i dalej Wag do Dunaju. Na orawskich podnóżach potoki babiogórskie uchodzą osobno do Czarnej Orawy i Polhoranki, nie tworząc cieku wyższego rzędu, jakim jest Skawica na północy (Łajczak 2004).

Masyw Babiej Góry zbudowany jest z utworów należących do płaszczowiny magurskiej (najwyższej jednostki tektonicznej Karpat Zewnętrznych), zbudowanej z fliszu jednostki raczańskiej na północnych stokach oraz bystrzyckiej na południowych stokach (Alexandrowicz 2004). Stok południowy budują formacje skalne kredowo-paleogeńskie, paleogeńskie oraz czwartorzędowe. Formacja kredowo-paleogeńska reprezentowana jest przez łupki i piaskowce (warstwy inoceramowe wieku kreda górna-paleocen). Formacja paleogeńska charakteryzuje się występowaniem piaskowców muskowitowych i łupków (piaskowce z Mutnego wieku paleoceńskiego), łupków i margli pstrych wieku paleoceńsko-eoceńskiego, łupki i piaskowce cienkoławicowe (warstwy beloweskie wieku eoceńskiego), margli i piaskowców (margle łąckie wieku eoceńskiego), piaskowce gruboławicowe i łupki piaskowce magurskie z Piwnicznej wieku eoceńsko-oligoceńskiego (Książkiewicz 1971; Watycha 1977; Wójcik i in. 2010). Utwory czwartorzędowe reprezentowane są przez żwiry, piaski, gliny, iły, głazy, bloki, rumosze wieku plejstoceńskiego oraz holoceńskie gliny, torfy, żwiry, piaski, bloki, głazy, iły, pakiety skalne (Książkiewicz 1971; Watycha 1977; Wójcik i in. 2010). Dominującym typem gleb są słabo przepuszczalne gleby brunatne kwaśne (Miechówka i in. 2004).

Według regionalizacji hydrogeologicznej Polski (Paczyński 1995; Paczyński, Sadurski 2007) obszar Babiej Góry należy do Makroregionu Południowego - Subregionu Karpackiego XV. Wody należą do Górskiej Prowincji Wisły oraz znajdują się w całości na terenie Zewnętrznej części Masywu Karpat. Na obszarze badań zlokalizowany jest Główny Zbiornik Wód Podziemnych 445 - Magura Babia Góra (Kleczkowski 1990). Zgodnie z podziałem na jednolite części wód podziemnych (JCWPd), analizowany obszar znajduje się w granicach JCWPd 152 i 161 (zgodnie z podziałem obowiązującym od 2004 do 2015 r.) oraz JCWPd 159 i 164 (zgodnie z podziałem mającym obowiązywać od 2016 r.) regionu Górnej Wisły w pasie Zewnętrznych Karpat Zachodnich. Zgodnie z podziałem JCWPd na obszarze badań występują dwa piętra wodonośne czwartorzędowe oraz trzeciorzędowe (fliszowe piętro wodonośne). Czwartorzędowe - holoceńskie i plejstoceńskie - piętro wodonośne budują głownie piaski i żwiry (tworzące ośrodek porowy), zaś paleogeńsko-kredowe piętro wodonośne charakteryzują utwory piaskowcowo-łupkowe fliszu karpackiego tworzące ośrodek szczelinowo-porowy (Postawa 2005).

Masyw Babiej Góry charakteryzuje się występowaniem głęboko spękanego podłoża skalnego piaskowca magurskiego oraz miąższych pokryw koluwialnych determinujących krążenie wody w obrębie stoku. Woda - infiltrując, a następnie krążąc przez długi czas - głęboko w tych utworach tworzy zasobny zbiornik wód podziemnych, który następnie ulega powolnemu opróżnianiu w formie odpływu podziemnego 
(Łajczak 1998, 2004). Z kolei odpływ w formie spływu powierzchniowego pojawia się na stokach masywu stosunkowo rzadko. Cechy te wyróżniają strukturę odpływu z Masywu Babiej Góry na tle innych pasm górskich w Beskidach, w których spływ powierzchniowy jest szybszy, a zasobność odpływu podziemnego jest znacznie niższa (Łajczak 1998). Jednym z obszarów o najwyższym odpływie jednostkowym w skali Polski jest masyw Babiej Góry (Łajczak 1988, 2004). W obrębie zlewni położonych na tym obszarze wartości współczynników odpływu oraz sezonowa zmienność odpływu jest bardzo zróżnicowana. Odpływ jednostkowy ze zlewni położonych na południowych stokach Babiej Góry wynosi średnio ok. $20 \mathrm{dm}^{3} \cdot \mathrm{s}^{-1} \cdot \mathrm{km}^{-2}$ (Łajczak 2004). W reżimie hydrologicznym odpływu ze zlewni potoków na terenie BgPN i jego otuliny zaznacza się wyraźne wiosenno-letnie maksimum. We wszystkich ciekach odwadniających masyw Babiej Góry stwierdzono występowanie ustroju rzecznego złożonego z dwoma kulminacjami (Łajczak 2004). Wyższy odpływ obserwuje się w okresie od marca do sierpnia, co jest związane z wiosennymi roztopami (marzec-maj) oraz w okresie letnim (czerwiec-lipiec) w związku z letnimi intensywnymi opadami deszczu. Z kolei niskie przepływy występujące jesienią i zimą (październik-luty) są konsekwencją niewielkich jesiennych opadów i retencji śniegowej w zimie (Pasterniak 1983). Reżim takiego odpływu charakteryzuje się jako typowy dla zlewni położonych w Karpatach Zachodnich (Franczak i in. 2015). Struktura odpływu w ciągu roku silnie zależy od warunków meteorologicznych panujących w danym roku hydrologicznym. W przypadku braku dużych opadów w półroczu letnim dominuje odpływ w okresie zimowym, natomiast w przypadku wystąpienia intensywnych opadów letnich dominuje odpływ z półrocza letniego (Franczak i in. 2015). W ciepłych i suchych latach hydrologicznych 2014 i 2015 z powodu braku intensywnych letnich opadów atmosferycznych wystąpiły jedynie wysokie odpływy w okresie wiosennym (marzec-maj) związane z wytapianiem pokrywy śnieżnej (ryc. 2, tab. 1); nie wystąpiły natomiast wezbrania letnie (ryc. 3, 4).

Na terenie masywu Babiej Góry występuje pięć pięter klimatycznych sprzężonych z piętrami roślinnymi (Obrębska-Starkel 1963; Holeksa, Szwagrzyk 2002). Wśród pięter klimatycznych wyróżnia się: umiarkowanie ciepłe (o średniej temperaturze $\left.8^{\circ} \mathrm{C}-6^{\circ} \mathrm{C}\right)$, umiarkowanie chłodne $\left(6^{\circ} \mathrm{C}-4^{\circ} \mathrm{C}\right)$, chłodne $\left(4^{\circ} \mathrm{C}-2^{\circ} \mathrm{C}\right)$, bardzo chłodne $\left(2^{\circ} \mathrm{C}-0^{\circ} \mathrm{C}\right.$ ) oraz umiarkowanie zimne $0^{\circ} \mathrm{C}$ do $-2^{\circ} \mathrm{C}$ (Obrębska-Starkel 1963). Pośród pięter roślinnych występuje: piętro pogórza (do ok. 700 m n.p.m.), regiel dolny (700 m n.p.m.-1150 m n.p.m.), regiel górny (1150 m n.p.m.-1360 m n.p.m.), zarośla kosodrzewiny powyżej górnej granicy lasu (1360 m n.p.m.-1650 m n.p.m.) oraz piętro alpejskie 1650 m n.p.m.-1725 m n.p.m. (Holeksa, Szwagrzyk 2002). Potoki Składziska, Sylec, Czarny, Kiczorka, Spod Jamy, Kuchyni, Wyłamany, Krzywy, Młynkówka, Szumiący, Lipniczanka oraz Przywarówka położone są w obrębie piętra klimatycznego umiarkowanego chłodnego (Obrębska-Starkel 1963), z roślinnością 


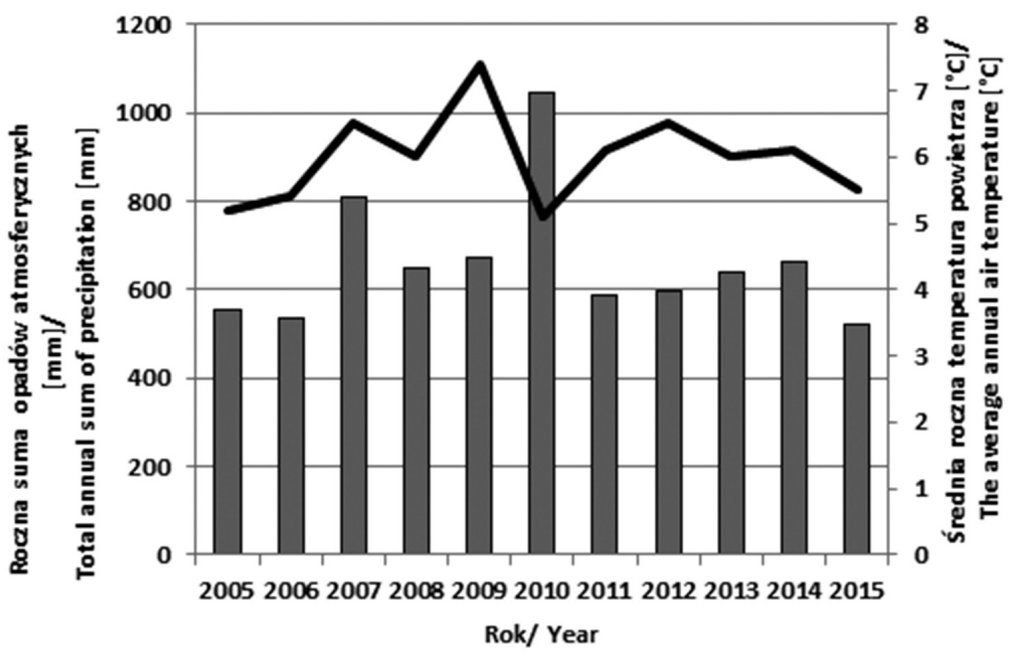

Rys. 2. Roczna suma opadów atmosferycznych wraz z średnią roczną temperaturą powietrza (w latach 2005-2015) ze stacji klimatycznej Kiczorka (1298 m n.p.m.)

Fig. 2. Annual precipitation with average annual air temperature (period 2005-2015) at the Kiczorka station (1298 m a.s.l.)
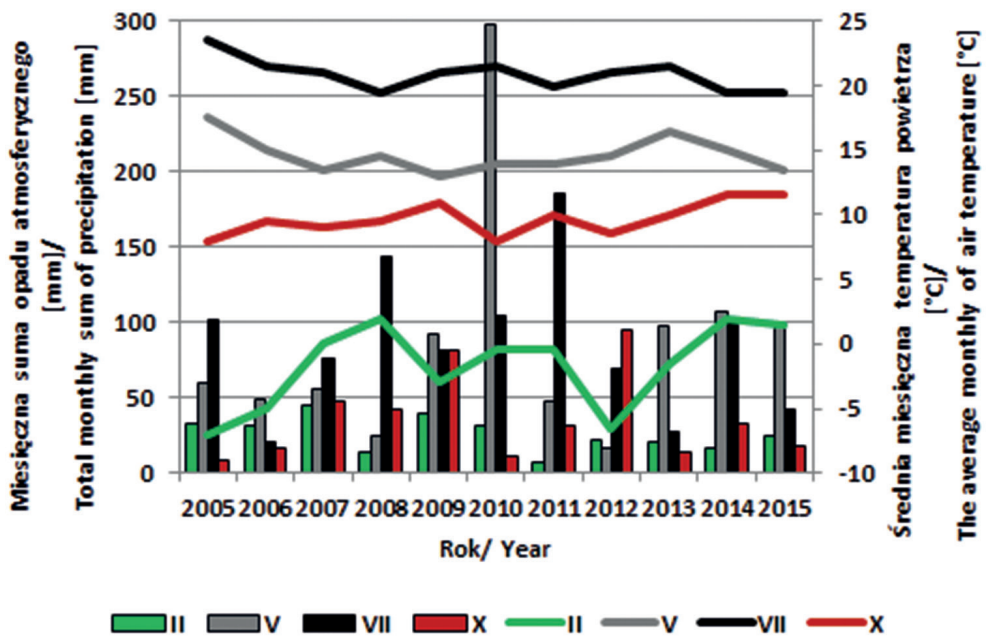

Rys. 3. Miesięczna suma opadów atmosferycznych wraz z średnią miesięczną temperaturą powietrza (w latach 2005-2015) ze stacji klimatycznej Kiczorka (1298 m n.p.m.)

Fig. 3. Monthly total precipitation with average monthly air temperature (period 2005-2015) at the Kiczorka station (1298 m a.s.l.) 


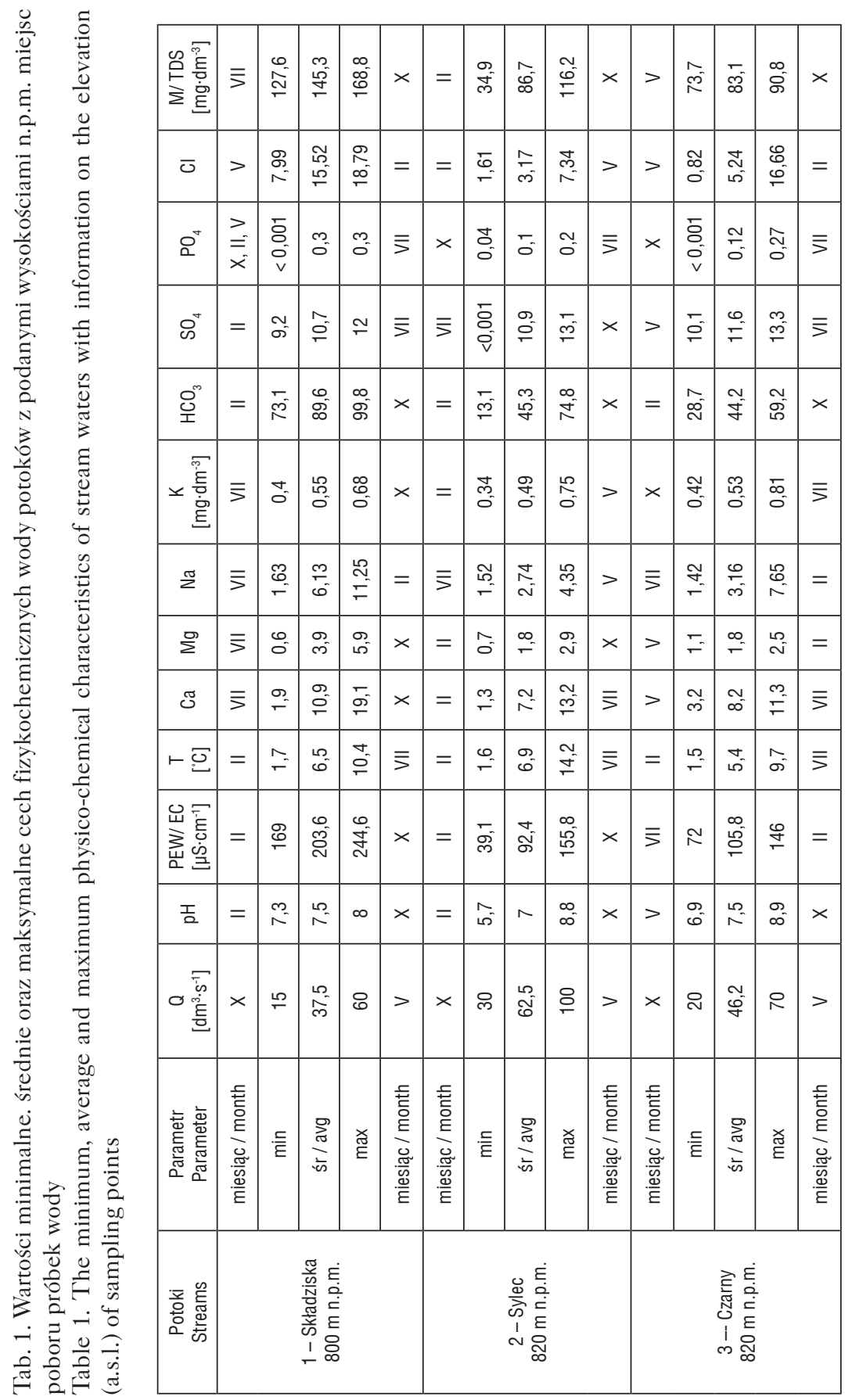




\begin{tabular}{|c|c|c|c|c|c|c|c|c|c|c|c|c|c|c|c|c|c|c|c|c|}
\hline 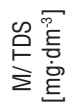 & $=$ & 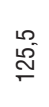 & $\begin{array}{l}m \\
\stackrel{m}{\sim} \\
\stackrel{5}{ \pm}\end{array}$ & $\begin{array}{l}\stackrel{+}{\circ} \\
\stackrel{\sigma}{\sigma}\end{array}$ & $\times$ & $>$ & 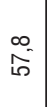 & \begin{tabular}{|l|} 
\\
0 \\
$\infty$ \\
$\infty$ \\
$\infty$
\end{tabular} & 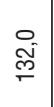 & $\times$ & $=$ & $\begin{array}{l}0 \\
i^{\circ}\end{array}$ & $\mid \begin{array}{l}0 \\
\mathbb{N} \\
\end{array}$ & $\hat{\tilde{\sigma}}$ & $\times$ & $\equiv$ & $\begin{array}{l}0 \\
0 \\
0\end{array}$ & $\stackrel{\infty}{\mathbb{N}}$ & $\stackrel{N}{N}$ & $=$ \\
\hline$\overline{0}$ & $\times$ & - & 文 & $\underset{\forall}{\stackrel{\Xi}{\sim}}$ & $>$ & $\bar{\xi}$ & $\stackrel{\circ}{\stackrel{\circ}{\rho}}$ & $\begin{array}{l}\bar{D} \\
\text { i } \\
\end{array}$ & $\frac{\stackrel{g}{m}}{m}$ & $=$ & $=$ & $\stackrel{\circ}{\stackrel{0}{\circ}}$ & $\mid \begin{array}{l}0 \\
\stackrel{2}{\sim} \\
\end{array}$ & $\stackrel{\mathscr{N}}{\stackrel{\leftrightarrow}{*}}$ & 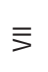 & $=$ & $\stackrel{\widetilde{n}}{\sim}$ & $\stackrel{8}{-}$ & $\stackrel{\dot{N}}{\sim}$ & $\times$ \\
\hline $8^{+}$ & $\times$ & ${ }_{0} \overline{0}$ & $\bar{\sigma}$ & हू & $\bar{\Sigma}$ & $\begin{array}{l}\vec{x} \\
\vec{x}\end{array}$ & $\begin{array}{l}\bar{\delta} \\
\dot{-} \\
\bar{v}\end{array}$ & $\begin{array}{l}8 \\
0 \\
0\end{array}$ & $\begin{array}{l}\infty \\
0 \\
0\end{array}$ & $\equiv$ & $\begin{array}{l}\vec{\equiv} \\
\bar{\equiv}\end{array}$ & $\begin{array}{l}\bar{\delta} \\
\dot{0} \\
0 \\
v\end{array}$ & $\cong$ & $\frac{0}{\circ}$ & $=$ & $>$ & $\begin{array}{l}\bar{\delta} \\
0 \\
0 \\
v\end{array}$ & $\begin{array}{l}\ddot{0} \\
0 \\
0\end{array}$ & 영 & $\begin{array}{l}= \\
\overline{\bar{\nu}}\end{array}$ \\
\hline க) $^{+}$ & $=$ & $\hat{F}$ & $\begin{array}{l}0 \\
\underset{\sim}{\square}\end{array}$ & 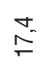 & $>$ & $>$ & $\widehat{\infty^{\circ}}$ & 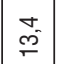 & $\begin{array}{l}\stackrel{\infty}{\sim} \\
\stackrel{-}{\sim}\end{array}$ & $\times$ & $\equiv$ & $\stackrel{\dot{m}}{\vec{m}}$ & $\mid \begin{array}{l}m \\
\infty^{-}\end{array}$ & $\stackrel{\cong}{\rightleftharpoons}$ & $\times$ & $\bar{\Sigma}$ & $\stackrel{\omega}{\sim}$ & $\stackrel{\infty}{N}$ & $\stackrel{m}{F}$ & $\times$ \\
\hline $\begin{array}{l}8^{\infty} \\
\text { 오 }\end{array}$ & $\bar{\xi}$ & 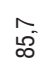 & $\begin{array}{l}\infty \\
0 \\
0 \\
0\end{array}$ & $\stackrel{\circ}{\rightleftharpoons}$ & $\times$ & $>$ & $\begin{array}{l}\text { ले } \\
\text { లె }\end{array}$ & \begin{tabular}{|l|}
\multirow{2}{*}{} \\
$\sigma$ \\
$\sigma$ \\
\end{tabular} & 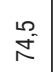 & $\times$ & $=$ & $\frac{m}{m}$ & 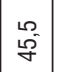 & $\overline{0}$ & $\times$ & $\equiv$ & $\begin{array}{l}\text { क् } \\
\text { ते }\end{array}$ & \begin{tabular}{l}
$\stackrel{\rho}{\sigma}$ \\
\multirow{2}{*}{}
\end{tabular} & $\bar{\sigma}$ & $=$ \\
\hline 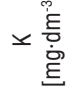 & $=$ & 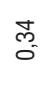 & $\tau$ & - & $\bar{\Sigma}$ & $=$ & $\begin{array}{l}\infty \\
0 \\
0 \\
0\end{array}$ & $\begin{array}{ll}\overline{5} \\
0 \\
0\end{array}$ & $\begin{array}{l}\mathbb{N} \\
\tilde{O}\end{array}$ & $\times$ & $=$ & $\begin{array}{l}f \\
\tilde{\sigma}\end{array}$ & $\begin{array}{l}\hat{n} \\
0 \\
0\end{array}$ & 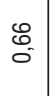 & $\equiv$ & $=$ & 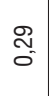 & ơ & $\stackrel{\infty}{\infty}$ & $\times$ \\
\hline$\stackrel{\pi}{2}$ & $\equiv$ & $\stackrel{\mathscr{R}}{\stackrel{\circ}{\circ}}$ & 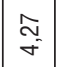 & $\begin{array}{l}\text { D. } \\
\infty \\
\infty\end{array}$ & $\times$ & $\equiv$ & - & $\begin{array}{l}\bar{\delta} \\
\dot{s} \\
\end{array}$ & $\begin{array}{c}\infty \\
0 \\
i n\end{array}$ & $\times$ & $\equiv$ & $\underset{-}{\underset{\sigma}{\sigma}}$ & $\underset{f}{\stackrel{f}{-}}$ & $\sim$ & $\times$ & $\equiv$ & $\stackrel{\Sigma}{\circ}$ & $\ddot{~}$ & $\stackrel{尺}{\stackrel{2}{r}}$ & $\times$ \\
\hline$\sum^{D}$ & $\bar{F}$ & 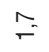 & $\hat{\sim}$ & $\stackrel{m}{*}$ & $>$ & $\stackrel{\geq}{=}$ & - & $\stackrel{\circ}{-}$ & $=$ & $\times$ & $=$ & $\begin{array}{l}\infty \\
\stackrel{0}{0}\end{array}$ & $=$ & $\stackrel{\text { po }}{=}$ & $\bar{\Sigma}$ & $=$ & $\stackrel{\infty}{\circ}$ & $=$ & 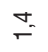 & $\times$ \\
\hline త్ర & $=$ & $\stackrel{L}{\sim}$ & $\hat{\simeq}$ & $\begin{array}{l}\infty^{\circ} \\
\stackrel{\infty}{\leftarrow}\end{array}$ & $>$ & $>$ & $\stackrel{\infty}{\sim}$ & $\bar{\sigma}$ & $\stackrel{\circ}{\circ}$ & $\times$ & $>$ & $\stackrel{\infty}{\sim}$ & $\begin{array}{l}\dot{\sigma} \\
\sigma^{\prime}\end{array}$ & $\mp$ & $\bar{\Sigma}$ & $>$ & $\stackrel{\infty}{-}$ & $\stackrel{g}{\sigma}$ & $\bar{\sigma}$ & $\bar{\Sigma}$ \\
\hline$\vdash \circlearrowright$ & $=$ & $\tilde{\sim}$ & $\cong$ & $\stackrel{m}{\longrightarrow}$ & $\equiv$ & $=$ & $\stackrel{0}{-}$ & $\wedge$ & $\begin{array}{l}\infty \\
\stackrel{\sim}{\sim}\end{array}$ & $\equiv$ & $=$ & $=$ & $\stackrel{\nabla}{\sim}$ & $\begin{array}{l}\stackrel{0}{0} \\
\stackrel{2}{p}\end{array}$ & 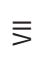 & $=$ & $\tilde{\sim}$ & $\begin{array}{c}\sim \\
\tilde{\sigma}\end{array}$ & $\begin{array}{l}\sigma_{0} \\
\stackrel{0}{0}\end{array}$ & $\equiv$ \\
\hline 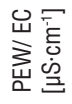 & $\bar{\Sigma}$ & $\approx$ & $\hat{m}$ & $\begin{array}{l}\infty \\
\stackrel{\infty}{\sigma}\end{array}$ & $\times$ & $\bar{\xi}$ & $\mathscr{8}$ & $\begin{array}{l}2 \\
\infty \\
\infty \\
\infty\end{array}$ & 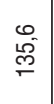 & $\times$ & $=$ & 今े & 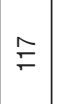 & $\begin{array}{l}0 \\
\text { : } \\
\text { N }\end{array}$ & $\times$ & $\equiv$ & $\bar{\sigma}$ & $\stackrel{\text { م) }}{\underset{N}{N}}$ & $\stackrel{尺}{\stackrel{2}{*}}$ & $\times$ \\
\hline 듬 & $=$ & $\wedge$ & $\stackrel{⿱}{N}$ & $\overline{c o}^{-}$ & $\times$ & $=$ & $\hat{0^{\circ}}$ & $\stackrel{\sim}{\sim}$ & $\begin{array}{c}\stackrel{N}{\infty} \\
\infty\end{array}$ & $\times$ & $=$ & $\hat{0}$ & $\stackrel{m}{N}$ & $\hat{\infty^{\circ}}$ & $\times$ & $>$ & $\begin{array}{l}20 \\
0 \\
0\end{array}$ & $\stackrel{N}{N}$ & $\bar{c}$ & $\times$ \\
\hline ○ & $\times$ & లి & $\frac{n}{15}$ & R & $>$ & $\times$ & 으 & 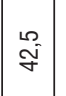 & $\stackrel{2}{R}$ & $>$ & $\times$ & ㄱ & $\mid$\begin{tabular}{l}
0 \\
\multirow{F}{*}{}
\end{tabular} & ㅇ & $>$ & $\times$ & $\stackrel{2}{\sim}$ & 氨 & $\approx$ & $>$ \\
\hline 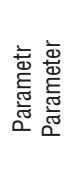 & 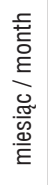 & 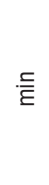 & 䞶 & 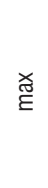 & 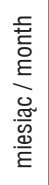 & 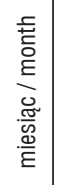 & 高 & 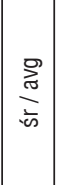 & 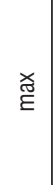 & 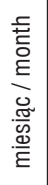 & 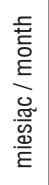 & 言 & 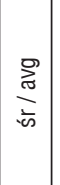 & 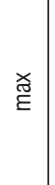 & 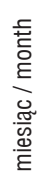 & 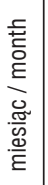 & 言 & 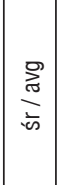 & 㸝 & 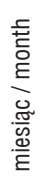 \\
\hline 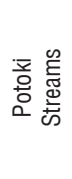 & & & 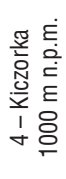 & & & & & 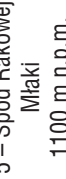 & & & & & 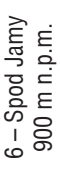 & & & & & 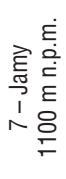 & & \\
\hline
\end{tabular}




\begin{tabular}{|c|c|c|c|c|c|c|c|c|c|c|c|c|c|c|c|c|c|c|c|c|}
\hline 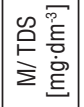 & $=$ & $\begin{array}{l}0 \\
\stackrel{\circ}{n}\end{array}$ & $\begin{array}{l}\infty \\
\infty \\
\infty\end{array}$ & $\begin{array}{l}\stackrel{\circ}{\circ} \\
\stackrel{0}{\circ}\end{array}$ & $\times$ & $>$ & 䙐 & $\stackrel{\infty}{\circ}$ & 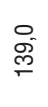 & $\times$ & $=$ & षे & $\underset{\tilde{N}}{\stackrel{\Xi}{\simeq}}$ & $\begin{array}{l}\tilde{N} \\
\tilde{\sim} \\
\end{array}$ & $\times$ & $=$ & $\mid \begin{array}{l}\infty \\
\overline{6}\end{array}$ & $\begin{array}{l}9 \\
0 \\
0 \\
\end{array}$ & $\bar{\sigma}$ & $x$ \\
\hline$\overline{0}$ & $x$ & $=$ & $\stackrel{\bar{\sigma}}{=}$ & $\stackrel{\mathscr{\Omega}}{-}$ & $=$ & $\times$ & $\stackrel{\Delta}{=}$ & $\stackrel{R}{=}$ & $\stackrel{\sim}{\sim}$ & $=$ & $\times$ & - & $\stackrel{m}{\sim}$ & $\underset{\mathcal{F}}{\mathcal{N}}$ & $>$ & $\bar{\Sigma}$ & 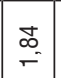 & : & 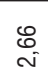 & $=$ \\
\hline $8^{+}$ & $>$ & $\begin{array}{l}\mathscr{8} \\
0 \\
0\end{array}$ & $\stackrel{\nabla}{0}$ & $\begin{array}{l}\mathscr{c} \\
\text { on }\end{array}$ & $\bar{\Sigma}$ & $\vec{x}$ & $\begin{array}{l}\overline{8} \\
0 \\
0 \\
v\end{array}$ & $\stackrel{2}{2}$ & $\begin{array}{l}2 \\
0 \\
0\end{array}$ & $=$ & $>$ & $\begin{array}{l}\bar{\delta} \\
\overline{0} \\
v\end{array}$ & $\begin{array}{l}8 \\
0 \\
0\end{array}$ & $\begin{array}{l}8 \\
0 \\
0\end{array}$ & $=$ & $\overrightarrow{=}$ & $\begin{array}{l}\bar{\delta} \\
\overline{0} \\
\bar{v}\end{array}$ & $\frac{m}{0}$ & $\frac{\sigma}{\sigma}$ & $\bar{\Sigma}$ \\
\hline के $^{+}$ & $\bar{\Sigma}$ & $\stackrel{\Delta}{\circ}$ & $\begin{array}{l}\infty \\
\infty^{-}\end{array}$ & $\bar{m}$ & $=$ & $\bar{\lessgtr}$ & - & $\stackrel{\infty}{\sim}$ & $\stackrel{\sigma}{\omega^{2}}$ & $\times$ & $\equiv$ & $\begin{array}{l}\bar{\delta} \\
\overline{0} \\
v\end{array}$ & Lم & $\stackrel{\sim}{\stackrel{n}{\sim}}$ & $>$ & $=$ & m. & $\stackrel{\cong}{F}$ & 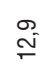 & $>$ \\
\hline 옹 & $=$ & $\stackrel{\infty}{\sim}$ & స్త్ర & $\stackrel{20}{N}$ & $\times$ & $>$ & శ్లి & 占 & 它 & $\times$ & $=$ & क्रे & $\begin{array}{l}\dot{\sigma} \\
8\end{array}$ & స̂े & $\times$ & $=$ & ๙ & $\begin{array}{l}n \\
\mathfrak{n} \\
\end{array}$ & $\begin{array}{l}\infty \\
0 \\
\end{array}$ & $\times$ \\
\hline$\simeq \begin{array}{c}\bar{c} \\
\bar{E} \\
\dot{\dot{g}} \\
\underline{E}\end{array}$ & $=$ & $\begin{array}{l}\infty \\
0 \\
0\end{array}$ & $\stackrel{\Xi}{\circ}$ & 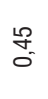 & $\times$ & $>$ & j్ & 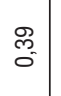 & 导 & $=$ & $>$ & $\widetilde{\widetilde{\sigma}}$ & L & $\begin{array}{l}\hat{\theta} \\
0\end{array}$ & $=$ & $\bar{\Sigma}$ & f & $\bar{\sigma}$ & $\begin{array}{l}\mathscr{D} \\
0 \\
0\end{array}$ & $\times$ \\
\hline$\frac{\pi}{2}$ & $>$ & $\stackrel{\mathrm{m}}{-}$ & 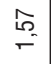 & $\stackrel{\mathscr{B}}{-}$ & $\times$ & $>$ & $\stackrel{\Delta}{-}$ & $\stackrel{\text { m్ }}{-}$ & $\stackrel{\hat{o}}{-}$ & $=$ & $\times$ & $\stackrel{\vec{m}}{=}$ & î & $\stackrel{m}{\infty}$ & 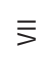 & $\equiv$ & $\mid \begin{array}{l}\infty \\
\stackrel{m}{-}\end{array}$ & $\begin{array}{l}\stackrel{\circ}{0} \\
\infty^{-}\end{array}$ & $\begin{array}{l}\hat{\sigma} \\
\forall\end{array}$ & $\times$ \\
\hline$\sum^{0}$ & $\times$ & $\hat{o}$ & $\cong$ & $\tilde{\sim}$ & $=$ & $>$ & $\because$ & $\stackrel{\nabla}{=}$ & $\tilde{\sim}$ & $\times$ & $=$ & $\stackrel{\circ}{-}$ & $\hat{\sim}$ & $\begin{array}{l}\infty \\
\underset{\sim}{*}\end{array}$ & $>$ & $=$ & $\tilde{N}$ & L & 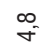 & $>$ \\
\hline త్ర & $x$ & $\stackrel{L}{\sim}$ & $\bar{\infty}$ & $\begin{array}{l}0 \\
0 \\
0\end{array}$ & $\bar{\Sigma}$ & $>$ & - & $\widehat{\hat{\theta}}$ & $\stackrel{m}{0}$ & $\bar{\Sigma}$ & $=$ & m & $\hat{\infty^{\circ}}$ & $\begin{array}{l}\text { 음 } \\
\underset{+}{+}\end{array}$ & $>$ & $=$ & $\stackrel{m}{N}$ & $\hat{\tilde{m}}$ & $\hat{\hat{N}}$ & $\times$ \\
\hline$\vdash \bar{U}$ & $=$ & $\stackrel{\circ}{\circ}$ & $\sim$ & $\hat{\tilde{N}}$ & $\equiv$ & $=$ & $\stackrel{\circ}{\sim}$ & $\stackrel{N}{N}$ & $\stackrel{m}{\longrightarrow}$ & $\equiv$ & $=$ & $\tilde{\sim}$ & $\hat{\imath}$ & $\begin{array}{l}\dot{0} \\
\stackrel{p}{\underline{p}}\end{array}$ & $\equiv$ & $=$ & $\sim$ & $\hat{0}$ & م్ & $\equiv$ \\
\hline 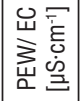 & $=$ & $\begin{array}{l}\stackrel{N}{\mathbb{N}} \\
\text { in }\end{array}$ & $\begin{array}{l}0 \\
\stackrel{0}{\infty}\end{array}$ & oे & $\times$ & $>$ & $\overline{6}$ & $\stackrel{\infty}{\aleph_{\infty}^{-}}$ & $\mp$ & $=$ & $=$ & 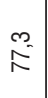 & $\underset{\frac{5}{5}}{\frac{5}{5}}$ & ळ & $\times$ & $=$ & 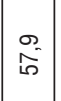 & $\begin{array}{l}\stackrel{0}{\sim} \\
\stackrel{2}{N}\end{array}$ & $\stackrel{\infty}{\stackrel{\infty}{\circ}}$ & $<$ \\
\hline 픔 & $=$ & $\begin{array}{l}L^{2} \\
0 \\
0\end{array}$ & $\begin{array}{l}0 \\
\tilde{\sigma}^{-}\end{array}$ & $\stackrel{\nabla}{\sim}$ & $\bar{\Sigma}$ & $>$ & $\widehat{\hat{\sigma}}$ & $\stackrel{\nabla}{\sim}$ & $\stackrel{+}{\infty}$ & $\times$ & $=$ & $\stackrel{0}{0}$ & $\stackrel{\sim}{\sim}$ & $\begin{array}{c}\infty \\
\infty^{-}\end{array}$ & $\times$ & $=$ & $\begin{array}{l}\dot{\sigma}_{-} \\
\dot{0}\end{array}$ & $\stackrel{\sim}{\sim}$ & $\stackrel{\circ}{\stackrel{9}{N}}$ & $\times$ \\
\hline 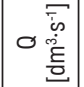 & $x$ & $\stackrel{2}{\sim}$ & \begin{tabular}{l}
20 \\
\multirow{8}{*}{}
\end{tabular} & $\stackrel{\infty}{\sim}$ & $>$ & $\times$ & ని & $\hat{q}$ & $\bowtie$ & $>$ & $\times$ & $\stackrel{ㅇ}{\longrightarrow}$ & $\hat{\sigma}$ & R & $>$ & $\times$ & 오 & مै & $\stackrel{\circ}{\circ}$ & \\
\hline 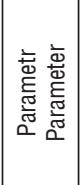 & 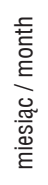 & 镸 & 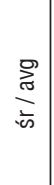 & $\stackrel{\underset{\Xi}{\Xi}}{E}$ & 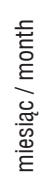 & 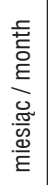 & 高 & 疍 & $\stackrel{\underset{\Xi}{E}}{ }$ & 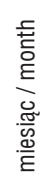 & 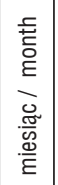 & 高 & 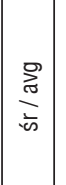 & $\stackrel{\text { ఝ }}{E}$ & 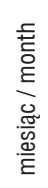 & 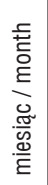 & 高 & 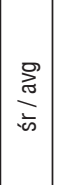 & $\stackrel{\text { 联 }}{E}$ & 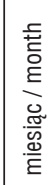 \\
\hline 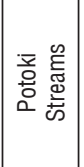 & & & 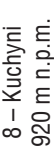 & & & & & 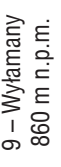 & & & & & 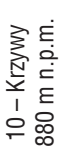 & & & & & 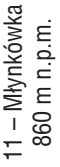 & & \\
\hline
\end{tabular}




\begin{tabular}{|c|c|c|c|c|c|c|c|c|c|c|c|c|c|c|c|}
\hline 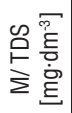 & $>$ & $\begin{array}{l}\infty \\
0 \\
L^{-}\end{array}$ & $\begin{array}{l}\infty \\
\infty^{-}\end{array}$ & $\begin{array}{l}\stackrel{\infty}{\sim} \\
\underset{\sim}{\sim}\end{array}$ & $\times$ & $=$ & $\begin{array}{l}\infty \\
\tilde{\sigma} \\
\tilde{\sigma}\end{array}$ & $\begin{array}{l}n \\
\mathscr{8} \\
\mathscr{8}\end{array}$ & \begin{tabular}{l}
\multirow{2}{*}{} \\
$\stackrel{2}{c}$
\end{tabular} & $\equiv$ & $>$ & $\begin{array}{l}n \\
\\
\end{array}$ & $\begin{array}{l}\infty \\
\mathscr{\delta}^{-}\end{array}$ & $\bar{\sigma}$ & $\times$ \\
\hline$\overline{0}$ & $\times$ & $\stackrel{0}{-}$ & $\stackrel{\stackrel{\leftrightarrow}{\circ}}{=}$ & $\begin{array}{l}\stackrel{8}{*} \\
\sim\end{array}$ & $\bar{\Sigma}$ & $\times$ & $\stackrel{\infty}{=}$ & $\begin{array}{l}\hat{\bar{v}} \\
\text { in }\end{array}$ & $\begin{array}{l}\stackrel{0}{N} \\
\sim\end{array}$ & $=$ & $=$ & $\begin{array}{l}\infty \\
\stackrel{\circ}{-}\end{array}$ & ì & $\stackrel{m}{\sim}$ & $\times$ \\
\hline$\AA^{+}$ & $>$ & E. & $\begin{array}{l}8 \\
0\end{array}$ & $E_{0}$ & $=$ & $\begin{array}{l}= \\
\bar{x} \\
\overline{\bar{y}}\end{array}$ & $\begin{array}{l}\bar{\delta} \\
\overline{0} \\
\bar{v}\end{array}$ & $\begin{array}{l}0 \\
0 \\
0\end{array}$ & $\ddot{0}$ & $>$ & $\times$ & $\tilde{\delta}$ & O. & $\begin{array}{l}\circ \\
\frac{0}{0}\end{array}$ & 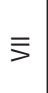 \\
\hline ¿ $^{+}$ & $\equiv$ & 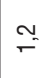 & $\begin{array}{l}\sigma^{\circ} \\
\infty^{\circ}\end{array}$ & $\begin{array}{l}\infty \\
\stackrel{\sim}{\sim}\end{array}$ & $\times$ & $\equiv$ & $\begin{array}{l}\bar{\delta} \\
\overline{0} \\
0 \\
v\end{array}$ & $\stackrel{\sim}{\simeq}$ & \begin{tabular}{l}
$\stackrel{\nabla}{ \pm}$ \\
\multirow{2}{*}{}
\end{tabular} & $\times$ & $>$ & $\underset{\infty}{\sigma}$ & $\stackrel{m}{0}$ & 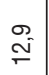 & $\times$ \\
\hline $\begin{array}{l}0^{\infty} \\
\text { 오 }\end{array}$ & $>$ & 守 & $\begin{array}{l}m \\
0 \\
0 \\
0\end{array}$ & $\overline{8}$ & $\times$ & $=$ & $\hat{\tilde{N}}$ & 8 & $\hat{8}$ & $\bar{\Sigma}$ & $\bar{\Sigma}$ & $\begin{array}{l}0 \\
\stackrel{m}{m}\end{array}$ & $\hat{\theta}$ & p్ & $\times$ \\
\hline 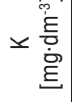 & $=$ & $\stackrel{m}{0}$ & ت্ & $\begin{array}{l}0 \\
i \\
0 \\
0\end{array}$ & $\bar{\xi}$ & $\equiv$ & $\stackrel{\overrightarrow{0}}{\circ}$ & 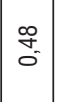 & $\begin{array}{l}0 \\
0 \\
0 \\
0\end{array}$ & $\times$ & $>$ & $\hat{\tilde{O}}$ & 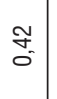 & $\begin{array}{l}\tilde{f} \\
\tilde{\sigma}\end{array}$ & $\equiv$ \\
\hline$\frac{\pi}{2}$ & $>$ & $\stackrel{\infty}{\stackrel{\infty}{\sim}}$ & $\stackrel{\nabla}{=}$ & $\underset{\sim}{\stackrel{\sim}{\sim}}$ & $\equiv$ & $\equiv$ & $\stackrel{g}{\stackrel{g}{-}}$ & $\mid \begin{array}{l}0 \\
\mathfrak{N} \\
\sim\end{array}$ & $\begin{array}{l}\stackrel{\circ}{\circ} \\
\stackrel{\sim}{*}\end{array}$ & $\times$ & 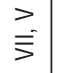 & 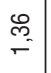 & $\stackrel{\text { 욤 }}{\sim}$ & 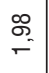 & $\times$ \\
\hline$\sum^{D}$ & $>$ & $=$ & $\bar{c}$ & $\bar{m}$ & $\bar{\Sigma}$ & $=$ & $\approx$ & $\stackrel{\sim}{\sim}$ & $\stackrel{\circ}{\dot{m}}$ & $\times$ & $>$ & - & $\cong$ & $\stackrel{m}{\sim}$ & $\equiv$ \\
\hline శ్ర & $>$ & $\stackrel{0}{\sim}$ & $\stackrel{20}{\circ}$ & $\begin{array}{l}\hat{\infty^{\circ}} \\
\tau^{-1}\end{array}$ & $\bar{\Sigma}$ & $>$ & $\sim$ & g) & $\begin{array}{c}\tilde{p} \\
\stackrel{p}{c}\end{array}$ & $\equiv$ & $>$ & $\stackrel{\circ}{-}$ & $\wedge$ & $\underset{\sigma}{\tau}$ & $\equiv$ \\
\hline$\vdash \bar{U}$ & $=$ & $\stackrel{m}{i}$ & $\begin{array}{l}\sigma \\
0 \\
0\end{array}$ & 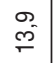 & $\equiv$ & $=$ & $\sim$ & \begin{tabular}{|l|}
$\infty$ \\
0 \\
$0^{-}$
\end{tabular} & $\stackrel{m}{\longrightarrow}$ & $\equiv$ & $=$ & $\bar{c}$ & $\wedge$ & $\begin{array}{l}\stackrel{s}{1} \\
\stackrel{\sim}{\sim}\end{array}$ & $\equiv$ \\
\hline $\begin{array}{l}\text { 它 } \\
\text { 总 } \\
\text { 它 }\end{array}$ & $>$ & $\begin{array}{l}\infty \\
0 \\
0^{-}\end{array}$ & $\begin{array}{l}\text { बे } \\
\text { षे }\end{array}$ & 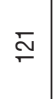 & $\bar{\Sigma}$ & $=$ & $\begin{array}{l}\text { o. } \\
\text { ôn }\end{array}$ & 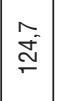 & Ф & $\times$ & $>$ & $\stackrel{m}{n}$ & $\stackrel{0}{\stackrel{\Xi}{\simeq}}$ & 怘 & $\times$ \\
\hline 돔 & $=$ & $\begin{array}{l}0 \\
0 \\
0\end{array}$ & $\Sigma$ & $\stackrel{+}{N}$ & $\equiv$ & $=$ & $\begin{array}{l}0 \\
0 \\
0\end{array}$ & $\stackrel{m}{\sim}$ & $\begin{array}{l}\stackrel{N}{\infty} \\
\infty\end{array}$ & $\times$ & $>$ & $\therefore$ & $\stackrel{\Delta}{\sim}$ & $=\bar{\infty}^{-}$ & $\times$ \\
\hline 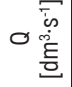 & $\times$ & ని & \begin{tabular}{l}
\multirow{2}{*}{} \\
ôt
\end{tabular} & $\triangleright$ & $>$ & $\times$ & 8 & $\stackrel{2}{2}$ & $\underset{\square}{\varnothing}$ & $>$ & $\times$ & R & 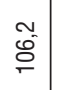 & $\stackrel{\stackrel{\&}{g}}{\sim}$ & $>$ \\
\hline 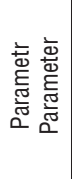 & 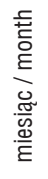 & 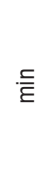 & 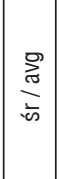 & 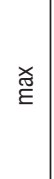 & 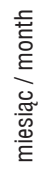 & 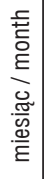 & 言 & 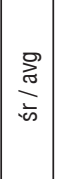 & 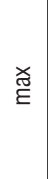 & 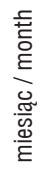 & 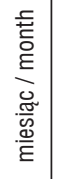 & 亳 & 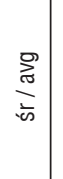 & $\stackrel{\underset{\Xi}{E}}{E}$ & 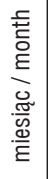 \\
\hline 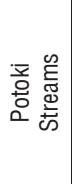 & & & 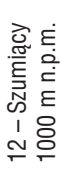 & & & & & 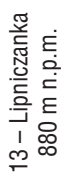 & & & & & 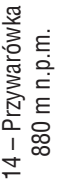 & & \\
\hline
\end{tabular}


regla dolnego lasu mieszanego bukowo-świerkowo-jodłowego (Holeksa, Szwagrzyk 2002). Potoki Spod Rakowej Młaki oraz Spod Jamy położone są w obrębie piętra klimatycznego chłodnego (Obrębska-Starkel 1963), w obrębie boru świerkowego regla górnego (Holeksa, Szwagrzyk 2002). Teren BgPN oraz jego otuliny pokryty jest w większości lasem, resztę obszaru zajmują łąki i pastwiska. Na obszarze badań występują zabudowania należące do nadleśnictwa Police oraz dyrekcji Babiogórskiego Parku Narodowego (leśniczówki oraz turystyczne stacje postojowe). Przez obszar przebiega również droga asfaltowa Rajsztag, udostępniana dla pobliskich mieszkańców (ryc. 1).

\section{Metodyka badań}

Podczas badań terenowych (lipiec i październik 2014 r., luty i maj 2015 r.) analizowano wysokości opadów atmosferycznych oraz temperatury powietrza z najbliższej stacji meteorologicznej Kiczorki 1298 m n.p.m (ryc. 2). Próbki wody z potoków pobrano w okresie aktywnym (w lipcu i w maju) oraz pasywnym (w październiku i w lutym) 2014 i 2015 r. Pobór wody wykonany został w celu zbadania zmienności sezonowej cech fizykochemicznych w zależności od pory roku. Za okres pasywny przyjmuje się miesiące, gdzie minimalna temperatura powietrza jest poniżej $0{ }^{\circ} \mathrm{C}$ (I-III, X-XII), a okres aktywny obejmuje pozostałe miesiące (Łajczak 2004). Reprezentatywność warunków meteorologicznych terminów poboru próbek wody poparta została minimum 3-dniowym okresem bezdeszczowym. Najniższa średnia temperatura powietrza w czasie pobierania próbek wody wyniosła $1,5^{\circ} \mathrm{C}$ w lutym, a najwyższą średnią temperaturę zanotowano w lipcu $-19,5^{\circ} \mathrm{C}$ (tab. 1). Najniższa suma opadów atmosferycznychwyniosła 24,9 mm w lutym 2015 r., a najwyższa 99,7 mm w lipcu 2014 r. (tab. 1) Dane meteorologiczne z 2014 i 2015 r. (ryc. 2, 3) porównano z danymi z 10-lecia (www.freemeteo.pl, 1.12.2015 r.). Pomiary temperatury powietrza i sum opadów atmosferycznych w okresie badań można uznać za typowe dla wielolecia $\mathrm{z}$ lat 2005-2015.

Dodatkowo, by potwierdzić wpływ opadów atmosferycznych na skład fizykochemiczny wód potoków, wykonano analizy opadów śniegu z obszaru badań. W okresie zimowym 2014 i 2015 r. pobrano 24 próbki śniegu do badań właściwości fizykochemicznych. Analizy obejmowały pomiary: $\mathrm{pH}$, przewodności elektrolitycznej właściwej (PEW) oraz stężeń jonów, tj. $\mathrm{Ca}, \mathrm{Mg}, \mathrm{Na}, \mathrm{K}, \mathrm{SO}_{4}, \mathrm{PO}_{4}, \mathrm{Cl}, \mathrm{Al}, \mathrm{Fe}, \mathrm{Mn}$.

Próbki wód z potoków pobierane były z punktów o zmierzonych dodatkowo wysokościach bezwzględnych. Opróbowano 14 potoków: Składziska (800 m n.p.m.), Sylec (820 m n.p.m.), Czarny (820 m n.p.m.), Kiczorka (1000 m n.p.m.), Spod Rakowej Młaki (1100 m n.p.m.), Spod Jamy (900 m n.p.m.), Jamy (1100 m n.p.m.), Kuchyni (920 m n.p.m.), Wyłamany (860 m n.p.m.), Krzywy (880 m n.p.m.), Młynkówka 
(860 m n.p.m.), Szumiący (1000 m n.p.m.), Lipniczanka (880 m n.p.m.) oraz Przywarówka (880 m n.p.m.).

Badania fizykochemiczne wód potoków objęły pomiary parametrów fizycznych i analizy chemiczne wybranych pierwiastków i związków chemicznych (makroelementy, mikroelementy). W terenie wykonano pomiary pH, PEW (przewodnictwa elektrolitycznego właściwego, czyli konduktancji) oraz temperatury wody. Wydajności przepływu potoków zmierzono metodą wolumetryczną. Pomiary terenowe parametrów wody wykonano za pomocą przenośnego miernika wielofunkcyjnego CPC-105 firmy Elmetron. Do polietylenowych butelek o pojemności 0,5 $\mathrm{dm}^{3}$ pobrano próbki wody do analiz chemicznych. Po przefiltrowaniu wody filtrem strzykawkowym $0,45 \mu \mathrm{m}$ próbki wody przechowywano w temperaturze $4^{\circ} \mathrm{C}$ do wykonania analiz laboratoryjnych (do $48 \mathrm{~h}$ od pobrania). Analizy chemiczne wody obejmowały oznaczenie głównych kationów (Ca, $\mathrm{Mg}, \mathrm{Na}, \mathrm{K})$, anionów $\left(\mathrm{HCO}_{3}, \mathrm{Cl}, \mathrm{SO}_{4}, \mathrm{PO}_{4}\right)$ oraz szeregu mikroelementów (Ag, Al, As, Be, Bi, Br, Cd, Co, Cr, Cs, Cu, Ga, I, Mo, Ni, $\mathrm{Pb}, \mathrm{Rb}, \mathrm{Sb}, \mathrm{Se}, \mathrm{Sn}, \mathrm{Te}, \mathrm{Ti}, \mathrm{Tl}, \mathrm{U}, \mathrm{V}, \mathrm{W}, \mathrm{Y}, \mathrm{Zr}$ ). Badania przeprowadzono w laboratorium Katedry Hydrogeologii i Geologii Inżynierskiej AGH w Krakowie. Badania wykonano za pomocą różnych metod analitycznych, by uzyskać najlepszą dokładność pomiaru stężeń pierwiastków i związków. Stężenia $\mathrm{HCO}_{3}$ oraz $\mathrm{Cl}$ oznaczono metodą wolumetryczną odpowiednio przez miareczkowanie kwasem solnym w obecności wskaźnika mieszanego oraz metodą argentometryczną (metoda Mohra). Metodą ICP OES za pomocą spektrofotometru emisyjnego z plazmą wzbudzoną indukcyjnie (Optima 7300 DV firmy Perkin Elmer) oznaczono jony główne, tj. Ca, Mg, K, Na, $\mathrm{SO}_{4}, \mathrm{PO}_{4}$. Metodą ICP MS przy zastosowaniu spektrometru masowego z plazmą wzbudzoną indukcyjnie (Elan 6100 firmy Perkin Elmer) oznaczono mikroelementy. Jakość wód potoków określono na podstawie obowiązujących w Polsce zakresów dopuszczalnych stężeń pierwiastków i związków (Rozporządzenie Ministra Zdrowia z 13 listopada 2015 r. w sprawie jakości wody przeznaczonej do spożycia przez ludzi).

\section{Wyniki badań}

Wyniki badań wód opadowych mogą służyć jako do scharakteryzowania „składowej wejściowej” wpływającej na ostateczny skład chemiczny wód potoków i wód podziemnych w rejonie badań. Wartość $\mathrm{pH}$ wody opadowej mieściła się w przedziale od 4,7 do 5,6, a PEW (konduktancja) od 21,2 do 61,7 $\mathrm{SS} \cdot \mathrm{cm}^{-1}$. Stężenia jonów $\left(\mathrm{mg} \cdot \mathrm{dm}^{-3}\right.$ ) wynosiły odpowiednio: $\mathrm{Ca}$ - od 0,3 do 2,87; $\mathrm{Mg}$ - od 0,04 do 0,22; $\mathrm{Na}-$ od 0,85 do 2,3; $\mathrm{K}-$ od 0,04 do 0,$17 ; \mathrm{SO}_{4}-$ od 1,6 do 2,2; $\mathrm{PO}_{4}-$ od 0,05 do 0,$14 ; \mathrm{Cl}-$ od 4,43 do 12,76; Al - od 0,003 do 0,01; Fe - od 0,003 do 0,009; Mn - od 0,001 do 0,003. Wody opadowe zaliczono do typu (Macioszczyk 1987) Ca-Na-Cl z dużym udziałem jonu siarczanowego $\mathrm{SO}_{4}$. 


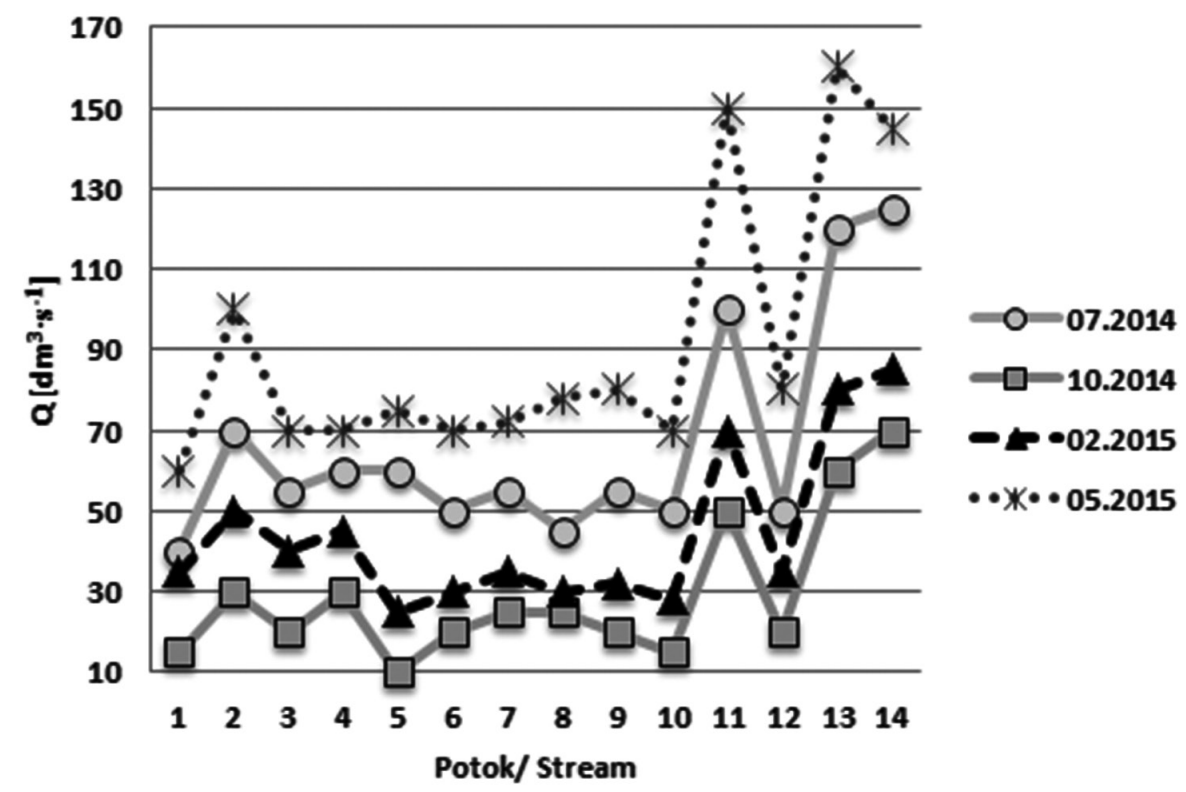

Rys. 4. Zarejestrowane natężenie przepływu potoków

Fig. 4. Investigated water streams discharges

Najwyższe natężenia przepływu potoków w okresie badań występowały wiosną, a najniższe jesienią (tab. 1). Najwyższy przepływ potoków zanotowano w maju $\left(160 \mathrm{dm}^{3} \cdot \mathrm{s}^{-1} \mathrm{w}\right.$ potoku Lipniczanka), co było spowodowane intensywnym topnieniem pokrywy śnieżnej wiosną, a najniższy jesienią $10 \mathrm{dm}^{3} \cdot \mathrm{s}^{-1} \mathrm{w}$ potoku Spod Rakowej Młaki (ryc. 4)

Wody analizowanych potoków zaliczono, zgodnie z zasadami klasyfikacji Szczukariewa-Prikłońskiego (Macioszczyk 1987), do typu hydrogeochemicznego $\mathrm{HCO}_{3}-\mathrm{Ca}-\mathrm{Mg} \mathrm{z}$ istotnym udziałem jonu siarczanowego $\mathrm{SO}_{4}$ (ryc. 5).

W większości przypadków najwyższe wartości $\mathrm{pH}$ wody badanych potoków obserwowano jesienią, a najniższe zimą. Najwyższą wartość pH $(8,9)$ zanotowano w potoku Czarnym w październiku, najniższą $(5,7)$ w potoku Sylec w lutym. Średni zakres pH analizowanych wód potoków mieścił się w przedziale 6,9-7,5. Pozwala to zaliczyć wody potoków do grupy wód obojętnych do słabo zasadowych (tab. 1, ryc. 6).

Przewodnictwo elektrolityczne właściwe (PEW) w większości przypadków osiągało najwyższe wartości jesienią, a najniższe latem. Maksymalną wartość $270 \mu \mathrm{S} \cdot \mathrm{cm}^{-1}$ zanotowano w październiku w potoku Jamy, a najniższą $56,1 \mu \mathrm{S} \cdot \mathrm{cm}^{-1} \mathrm{~W}$ potoku 


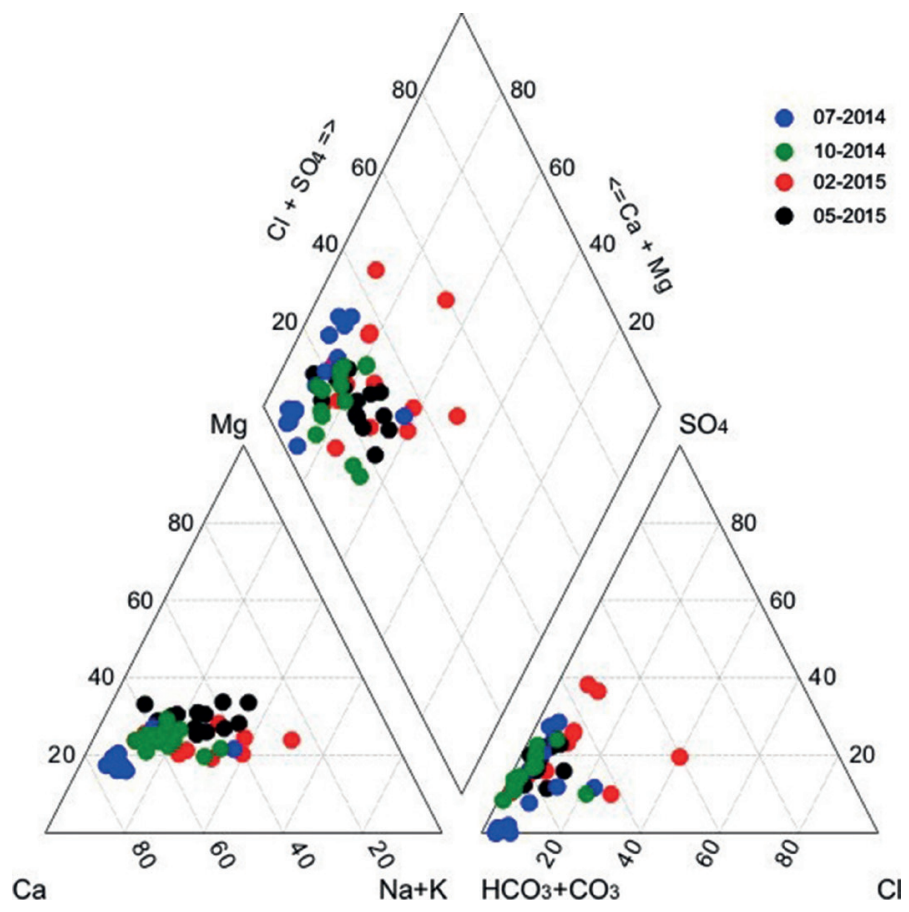

Rys. 5. Diagram Pipera dla badanych wód potoków

Fig. 5. Piper diagram for the tested water streams

Wyłamanym w maju. Średnia wartość PEW od 83,8 do 203,6 $\mathrm{SS} \cdot \mathrm{cm}^{-1}$ odpowiadała zakresowi wód niskozmineralizowanych (tab. 1, ryc. 6). Wyniki badań potwierdziły zasygnalizowany przez Pasternaka (1983) odczyn obojętny wód na Babiej Górze, który w profilu wysokościowym zawiera się w granicach 7,8-8,9. Niska mineralizacja wód powoduje, że wody potoków są podatne na zmiany źródeł dostawy jonów i metali ciężkich (Malata, Motyka, 2015).

Najwyższa temperatura wody badanych potoków występowała latem, a najniższa zimą. W lipcu zmierzono najwyższą temperaturę wody $\left(14,2^{\circ} \mathrm{C}\right) \mathrm{w}$ potoku Sylec, najniższą $\left(1,1^{\circ} \mathrm{C}\right)$ w lutym w potoku Spod Jamy. Średnia wartość temperatury wody analizowanych potoków wahała się od $5,4^{\circ} \mathrm{C}$ do $7,9^{\circ} \mathrm{C}$. Jest to zgodne ze stwierdzeniem Łajczaka (2004), że średnia temperatura wody nie spada poniżej $4^{\circ} \mathrm{C}$ bez względu na porę roku na obszarze masywu Babiej Góry (tab. 1, ryc. 6).

Brak wyraźnych prawidłowości w występowaniu kationów głównych kationów (Ca, Mg, Na, K) w wodach potoków (tab. 1). Stężenie Ca w większości punktów pomiarowych najwyższe wartości osiągało latem, a najniższe wiosną, ale najwyższe 

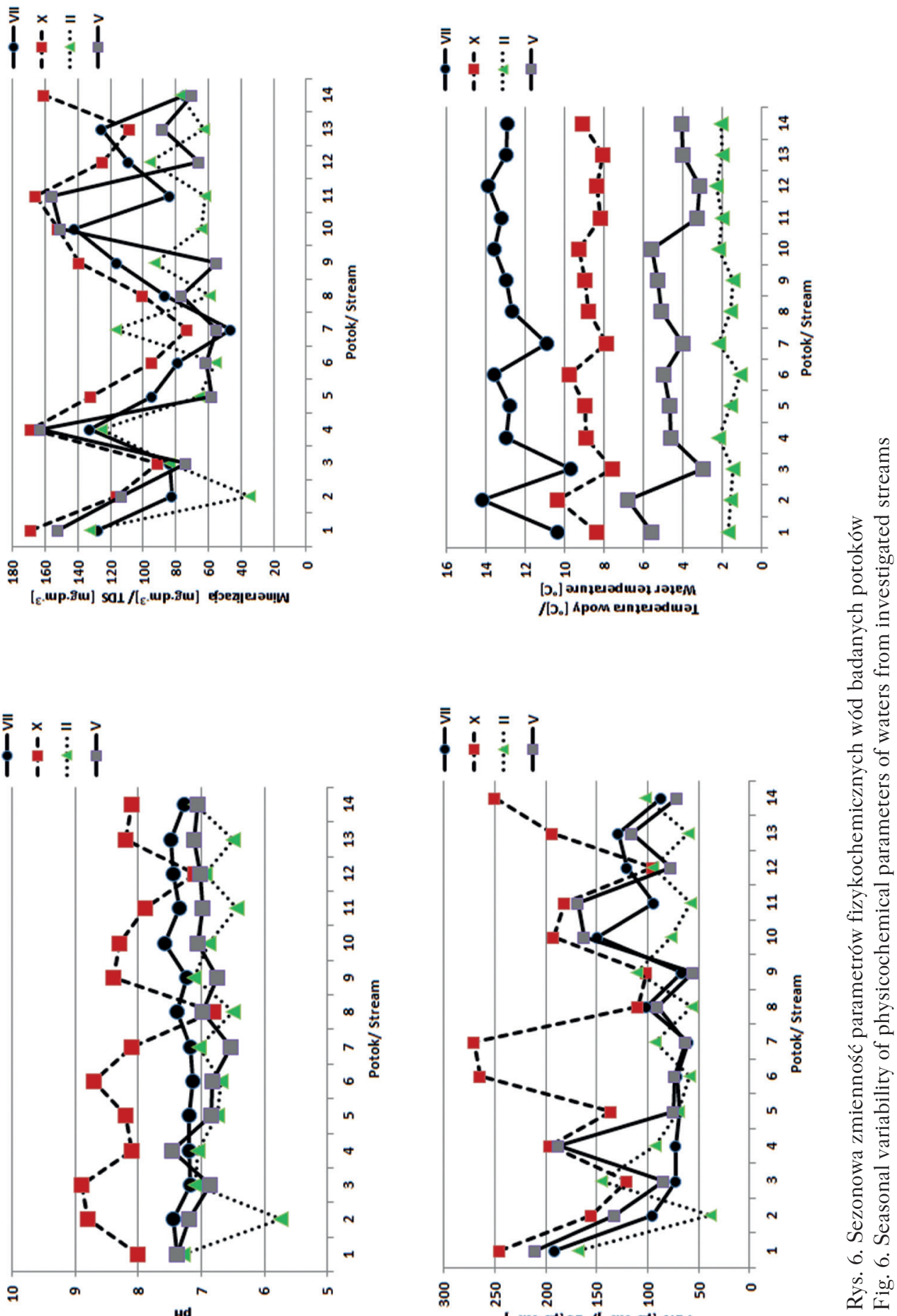

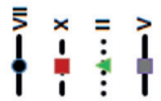

$\begin{array}{lll}\overline{1} & = \\ 1 & \vdots & \\ 1 & \vdots & 1\end{array}$
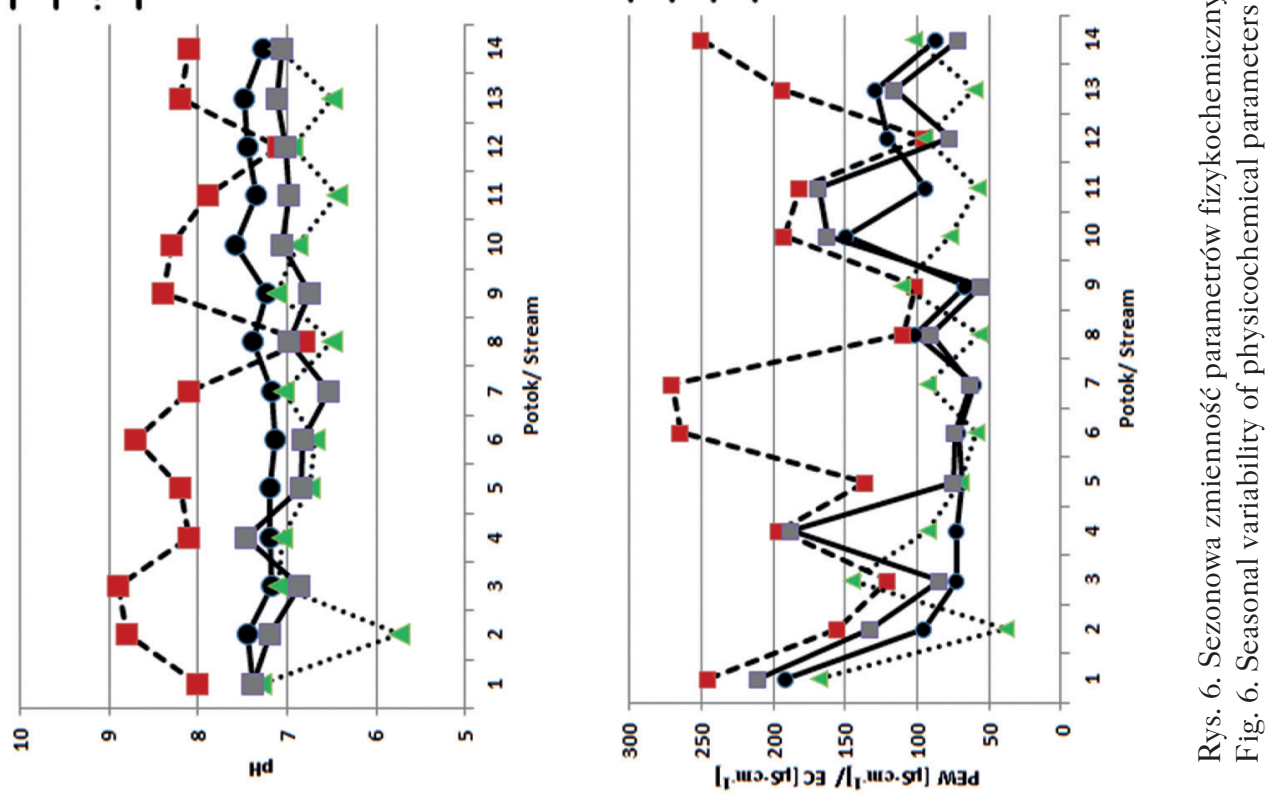
stężenie Ca (20,6 $\left.\mathrm{mg} \cdot \mathrm{dm}^{-3}\right)$ zanotowano w październiku w potoku Spod Rakowej Młaki. Najwyższe stężenie $\mathrm{Mg}\left(5,9 \mathrm{mg} \cdot \mathrm{dm}^{-3}\right)$ zanotowano w październiku w potoku Składziska, najniższe $\left(0,6 \mathrm{mg} \cdot \mathrm{dm}^{-3}\right)$ w lipcu w potoku Składziska (tab. 1). Stężenia $\mathrm{Na}$ zmieniały się w przedziale od $1,04 \mathrm{mg} \cdot \mathrm{dm}^{-3}$ (w maju w potoku Wyłamanym) do $11,25 \mathrm{mg} \cdot \mathrm{dm}^{-3} \mathrm{w}$ lutym w potoku Składziska. Najwyższe stężenie K $\left(0,9 \mathrm{mg} \cdot \mathrm{dm}^{-3}\right)$ zanotowano w lipcu w potoku Kiczorka, najniższe $\left(0,29 \mathrm{mg} \cdot \mathrm{dm}^{-3}\right)$ w lutym w potoku Jamy.

W grupie anionów głównych najwyższe stężenie $\mathrm{HCO}_{3}\left(130 \mathrm{mg} \cdot \mathrm{dm}^{-3}\right)$ zanotowano w październiku w potoku Przywarówka, najniższe $\left(13,1 \mathrm{mg} \cdot \mathrm{dm}^{-3}\right)$ w lutym w potoku Sylec (tab. 1). Odwrotną zależność zaobserwować można dla jonów chlorkowych. Najwyższe stężenie Cl $\left(18,79 \mathrm{mg} \cdot \mathrm{dm}^{-3}\right)$ zanotowano w lutym w potoku Składziska, najniższe $\left(0,82 \mathrm{mg} \cdot \mathrm{dm}^{-3}\right) \mathrm{w}$ maju w potoku Czarnym.

Stężenie jonu siarczanowego $\left(\mathrm{SO}_{4}\right)$ w większości punktów poboru próbek najwyższe wartości osiągało jesienią, a najniższe latem. Maksymalne stężenie $\mathrm{SO}_{4}$ $\left(17,7 \mathrm{mg} \cdot \mathrm{dm}^{-3}\right)$ zanotowano w październiku, w potoku Spod Rakowej Młaki, minimalne zaś $\left(<0,001 \mathrm{mg} \cdot \mathrm{dm}^{-3}\right)$ w lipcu, w potokach Sylec i Lipniczanka (tab. 1). Odwrotną tendencję zaobserwowano w przypadku $\mathrm{PO}_{4}$, którego najwyższe stężenie $\left(0,31 \mathrm{mg} \cdot \mathrm{dm}^{-3}\right)$ zanotowano w lipcu w potoku Kiczorka, najniższe zaś $\left(<0,001 \mathrm{mg} \cdot \mathrm{dm}^{-3}\right)$ w październiku m.in. w potoku Czarnym.

W wodach trzech potoków stężenia srebra (Ag) były wyższe od wartości dopuszczalnych określonych w przepisach dotyczących wód przeznaczonych do spożycia przez ludzi (Rozp Min. Zdrowia z 2015 r.). Podwyższone stężenia Ag występowały w wodach we wszystkich przypadkach latem. Przekroczenia stężenia Ag (przy wartości dopuszczalnej wynoszącej $10 \mu \mathrm{g} \cdot \mathrm{dm}^{-3}$ ) objęły wody potoków: Składziska, Kiczorka oraz Spod Rakowej Młaki. W lipcu zanotowano przekroczenia dopuszczalnego stężenia w wodach potoków: Składziska (najwyższa wartość wyniosła $32,83 \mu \mathrm{g} \cdot \mathrm{dm}^{-3}$ ), Kiczorka 25,41 $\mu \mathrm{g} \cdot \mathrm{dm}^{-3}$ oraz Spod Rakowej Młaki 67,31 $\mu \mathrm{g} \cdot \mathrm{dm}^{-3}$ (tab. 2, ryc. 7).

Dopuszczalne stężenie glinu (Al) dla wód przeznaczonych do spożycia przez ludzi (Rozp. Min. Zdrowia z 2015 r.) zostało przekroczone w wodach 9 potoków. Podwyższone stężenia Al w wodach występowały latem, jesienią i zimą. Przekroczenia stężenia Al (przy dopuszczalnej $200 \mu \mathrm{g} \cdot \mathrm{dm}^{-3}$ ) objęły wody następujących potoków: Sylec, Czarny, Kiczorka, Spod Rakowej Młaki, Spod Jamy, Jamy, Krzywy, Młynkówka oraz Lipniczanka. W lipcu zanotowano przekroczenia dopuszczalnego stężenia w wodach potoków: Czarny (najwyższa wartość wyniosła $1042 \mu \mathrm{g} \cdot \mathrm{dm}^{-3}$ ), Kiczorka $1102 \mu \mathrm{g} \cdot \mathrm{dm}^{-3}$ oraz Spod Jamy $403 \mu \mathrm{g} \cdot \mathrm{dm}^{-3}$. W lutym zanotowano przekroczenia stężeń w wodach potoków: Sylec (najwyższa wartość wyniosła $536 \mu \mathrm{g} \cdot \mathrm{dm}^{-3}$ ), Spod Rakowej Młaki $232 \mu \mathrm{g} \cdot \mathrm{dm}^{-3}$, Spod Jamy $226 \mu \mathrm{g} \cdot \mathrm{dm}^{-3}$, Krzywy $1180 \mu \mathrm{g} \cdot \mathrm{dm}^{-3}$, Młynkówka $602 \mu \mathrm{g} \cdot \mathrm{dm}^{-3}$ oraz Lipniczanka $602 \mu \mathrm{g} \cdot \mathrm{dm}^{-3}$. W październiku zanotowano przekroczenia stężeń w wodach potoków: Spod Jamy (najwyższa wartość wyniosła $480 \mu \mathrm{g} \cdot \mathrm{dm}^{-3}$ ) oraz Młynkówka - $300 \mu \mathrm{g} \cdot \mathrm{dm}^{-3}$ (tab. 2, ryc. 7). 

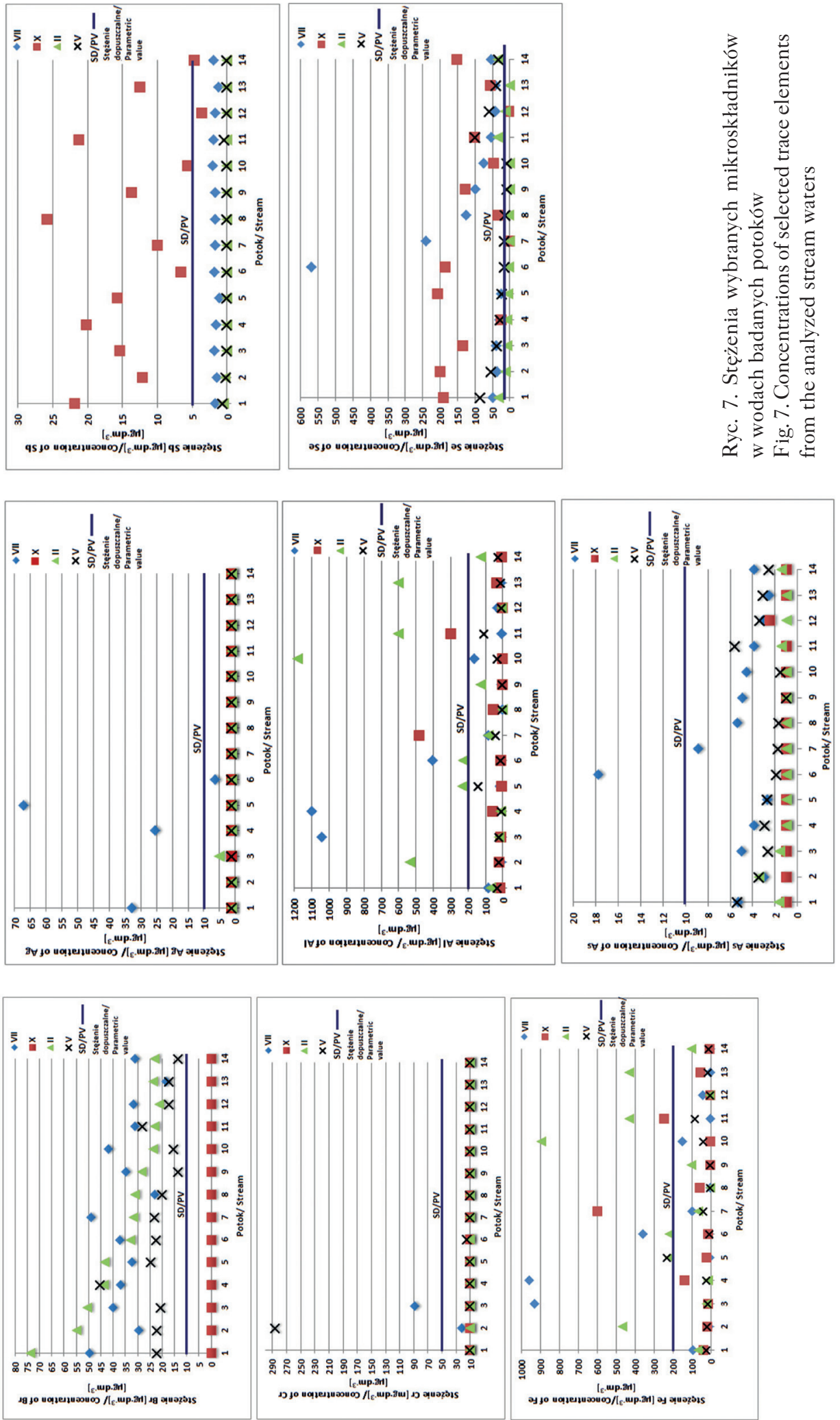
Z kolei dopuszczalne stężenie arsenu (As) dla wód przeznaczonych do spożycia przez ludzi (Rozp. Min. Zdrowia z 2015 r.) zostało przekroczone w wodzie potoku Jamy latem. Przekroczenie stężenia As w wodzie w lipcu (przy dopuszczalnym $10 \mu \mathrm{g} \cdot \mathrm{dm}^{-3}$ ) wyniosło $17,8 \mu \mathrm{g} \cdot \mathrm{dm}^{-3}$ (tab. 2, ryc. 7).

W wodach 14 potoków przekroczone zostało dopuszczalne stężenie bromu (Br) dla wód przeznaczonych do spożycia przez ludzi (Rozp. Min. Zdrowia z 2015 r.). Podwyższone stężenia Br w wodach występowały latem, zimą i wiosną. Przekroczenia stężenia $\mathrm{Br}$ (przy dopuszczalnej $10 \mu \mathrm{g} \cdot \mathrm{dm}^{-3}$ ) objęły wody potoków: Składziska, Sylec, Czarny, Kiczorka, Spod Rakowej Młaki, Spod Jamy, Jamy, Kuchyni, Wyłamany, Krzywy, Młynkówka, Szumiący, Lipniczanka oraz Przywarówka. W lipcu zanotowano przekroczenia dopuszczalnego stężenia w wodach potoków: Spod Jamy (najwyższa wartość wyniosła 37,24 $\mu \mathrm{g} \cdot \mathrm{dm}^{-3}$ ), Jamy 48,91 $\mu \mathrm{g} \cdot \mathrm{dm}^{-3}$, Wyłamany 34,71 $\mu \mathrm{g} \cdot \mathrm{dm}^{-3}$, Krzywy 41,88 $\mu \mathrm{g} \cdot \mathrm{dm}^{-3}$, Młynkówka 31,2 $\mu \mathrm{g} \cdot \mathrm{dm}^{-3}$, Szumiący $31,76 \mu \mathrm{g} \cdot \mathrm{dm}^{-3}$ oraz Przywarówka $31,2 \mu \mathrm{g} \cdot \mathrm{dm}^{-3}$. W lutym zanotowano przekroczenia stężeń w wodach potoków: Składziska (najwyższa wartość wyniosła 73,86 $\mu \mathrm{g} \cdot \mathrm{dm}^{-3}$ ), Sylec 54,89 $\mu \mathrm{g} \cdot \mathrm{dm}^{-3}$, Czarny 50,56 $\mu \mathrm{g} \cdot \mathrm{dm}^{-3}$, Spod Rakowej Młaki 43,54 $\mu \mathrm{g} \cdot \mathrm{dm}^{-3}$, Kuchyni 31,19 $\mu \mathrm{g} \cdot \mathrm{dm}^{-3}$ oraz Lipniczanka 23,65 $\mu \mathrm{g} \cdot \mathrm{dm}^{-3}$. W maju zanotowano przekroczenie stężenia w wodzie potoku Kiczorka, najwyższa wartość wyniosła $45,29 \mu \mathrm{g} \cdot \mathrm{dm}^{-3}$ (tab. 2, ryc. 7).

Z kolei dopuszczalne stężenie chromu (Cr) dla wód przeznaczonych do spożycia przez ludzi (Rozp. Min. Zdrowia z 2015 r.) zostało przekroczone w wodach dwóch potoków. Podwyższone stężenia Cr w wodach występowały wiosną i latem. Przekroczenia stężenia Cr (przy dopuszczalnej $50 \mu \mathrm{g} \cdot \mathrm{dm}^{-3}$ ) objęły wody potoków Sylec oraz Czarny. W lipcu zanotowano przekroczenie dopuszczalnego stężenia w wodzie potoku Czarnego, najwyższa wartość wyniosła 88,51 $\mu \mathrm{g} \cdot \mathrm{dm}^{-3}$. W maju zanotowano przekroczenie stężenia w wodzie potoku Sylec, najwyższa wartość wyniosła $285,84 \mu \mathrm{g} \cdot \mathrm{dm}^{-3}$ (tab. 2, ryc. 7).

Dopuszczalne stężenie żelaza $(\mathrm{Fe})$ dla wód przeznaczonych do spożycia przez ludzi (według. Rozp. Min. Zdrowia z 2015 r.) zostało przekroczone w wodach dziewięciu potoków. Podwyższone stężenia Fe w wodach występowało latem, zimą oraz wiosną. Przekroczenia stężenia Fe (przy dopuszczalnej $200 \mu \mathrm{g} \cdot \mathrm{dm}^{-3}$ ) objęły wody potoków: Sylec, Czarny, Kiczorka, Spod Rakowej Młaki, Spod Jamy, Jamy, Krzywy, Młynkówka oraz Lipniczanka. W lipcu zanotowano przekroczenia dopuszczalnego stężenia w wodach potoków: Czarny (najwyższa wartość wyniosła $934 \mu \mathrm{g} \cdot \mathrm{dm}^{-3}$ ), Kiczorka $961 \mu \mathrm{g} \cdot \mathrm{dm}^{-3}$ oraz Spod Jamy $358 \mu \mathrm{g} \cdot \mathrm{dm}^{-3}$. W październiku zanotowano przekroczenie stężenia w wodzie potoku Jamy, najwyższa wartość wyniosła $600 \mu \mathrm{g} \cdot \mathrm{dm}^{-3}$. W lutym zanotowano przekroczenia stężeń w wodach potoków: Sylec (najwyższa wartość wyniosła $\left.469 \mu \mathrm{g} \cdot \mathrm{dm}^{-3}\right)$, Krzywy $895 \mu \mathrm{g} \cdot \mathrm{dm}^{-3}$, Młynkówka $430 \mu \mathrm{g} \cdot \mathrm{dm}^{-3}$ oraz Lipniczanka $430 \mu \mathrm{g} \cdot \mathrm{dm}^{-3}$. W maju zanotowano przekroczenie stężenia $\mathrm{W}$ wodzie potoku Spod Rakowej Młaki, najwyższa wartość wyniosła $231 \mu \mathrm{g} \cdot \mathrm{dm}^{-3}$ (tab. 2, ryc. 7). 


\begin{tabular}{|c|c|c|c|c|c|c|c|c|c|c|c|c|c|c|c|c|c|c|c|}
\hline & 3 & $\begin{array}{l}\delta \\
\delta \\
0 \\
v\end{array}$ & $\begin{array}{l}0 \\
\mathbb{N} \\
\mathscr{8}\end{array}$ & $\begin{array}{l}\bar{\sigma} \\
\overline{0} \\
\bar{v}\end{array}$ & 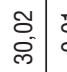 & \begin{tabular}{l|l}
$\delta$ & 0 \\
$\vdots$ & 0 \\
0 & 0 \\
0
\end{tabular} & $\begin{array}{l}\bar{\delta} \\
\bar{v} \\
v\end{array}$ & $\tilde{\widetilde{N}}$ & $\mid \begin{array}{l}\bar{\delta} \\
0 \\
\bar{v} \\
\bar{v}\end{array}$ & $\underset{f}{\stackrel{f}{*}}$ & \begin{tabular}{l|l}
- & 0 \\
$\infty$ & 0 \\
0 & 0 \\
0
\end{tabular} & $\mid$\begin{tabular}{l|}
$\bar{\delta}$ \\
0 \\
0 \\
$v$
\end{tabular} & $\begin{array}{l}\stackrel{2}{\sim} \\
\underset{+}{\leftarrow}\end{array}$ & $\begin{array}{l}\bar{\delta} \\
\bar{v} \\
\bar{v}\end{array}$ & $\begin{array}{l}\stackrel{\Delta}{S} \\
\stackrel{\sigma}{\sigma}\end{array}$ & $\begin{array}{l}\bar{\delta} \\
\bar{v} \\
\bar{v}\end{array}$ & \begin{tabular}{l}
$\underset{\sigma}{\sigma}$ \\
\multirow{\sigma}{*}{}
\end{tabular} & $\begin{array}{l}\delta \\
\overline{0} \\
\bar{v}\end{array}$ & $\begin{array}{l}\text { న్ } \\
\text { o. }\end{array}$ \\
\hline & $\supset$ & $\bar{v}$ & $\mid$\begin{tabular}{l|} 
\\
$\infty$ \\
$\infty$ \\
$\infty$
\end{tabular} & $\bar{v}$ & \begin{tabular}{l|}
$\infty$ \\
$\infty$ \\
$\infty$ \\
$\infty^{-}$
\end{tabular} & $\bar{v} \mid \stackrel{o}{-}$ & $\bar{v}$ & $\stackrel{\cong}{\rightleftharpoons}$ & $\bar{v}$ & $\frac{\simeq}{0}$ & \begin{tabular}{l|l}
$\bar{v}$ & $\underset{\sim}{\mathbb{N}}$
\end{tabular} & $\bar{v}$ & $\left|\begin{array}{c|}0 \\
\infty^{-}\end{array}\right|$ & $\bar{v}$ & $\frac{m}{\sigma}$ & $\bar{v}$ & 疍 & $\bar{v}$ & $\underset{\mathscr{R}}{\sim}$ \\
\hline & $i=$ & $\bar{v}$ & $\hat{\sim}$ & $\bar{v}$ & 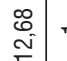 & $\bar{v} \mid \frac{\nabla}{\sigma}$ & $\bar{v}$ & 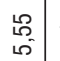 & $\bar{v}$ & \begin{tabular}{c|}
$g$ \\
$\underset{\infty}{q}$ \\
$\infty$
\end{tabular} & $\bar{v} \mid \stackrel{g}{\stackrel{g}{N}}$ & $\bar{v}$ & 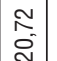 & $\bar{v}$ & $\begin{array}{c}\bar{m} \\
\sim \\
\sim\end{array}$ & $\bar{v}$ & $\begin{array}{l}\sigma \\
\underset{\sigma}{-}\end{array}$ & $\bar{v}$ & $\bar{m}$ \\
\hline & के & 0 & $\mathbb{N}$ & 으 & g & $F \quad 8$ & $\bar{m}$ & $\stackrel{\infty}{\rightleftharpoons}$ & $\wedge$ & $\underset{m}{\stackrel{m}{m}}$ r & $\wedge$ & ما & 尺 & $\wedge$ & 눙 & $\sigma$ & $\bar{\gamma}$ & $\stackrel{m}{-2}$ & $\approx$ \\
\hline & ल5 & $\mid \begin{array}{l}\bar{\delta} \\
\overline{0} \\
\bar{v}\end{array}$ & \begin{tabular}{|l|} 
\\
$\infty$ \\
$\infty$ \\
$O$ \\
\end{tabular} & $\begin{array}{l}\bar{\delta} \\
\overline{0} \\
\bar{v}\end{array}$ & 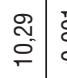 & 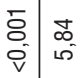 & $\begin{array}{l}\bar{\delta} \\
\bar{v} \\
\bar{v}\end{array}$ & $\stackrel{\circ}{\stackrel{2}{N}}$ & $\begin{array}{l}\bar{\delta} \\
\overline{0} \\
\bar{v}\end{array}$ & $\stackrel{g}{=}$ & 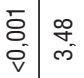 & $\mid \begin{array}{l}\bar{\delta} \\
\overline{0} \\
\bar{v}\end{array}$ & 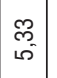 & $\begin{array}{l}\bar{\delta} \\
\bar{v} \\
\bar{v}\end{array}$ & ${ }_{0}$ & $\begin{array}{l}\bar{\delta} \\
\bar{v} \\
\bar{v}\end{array}$ & \begin{tabular}{l|}
$\infty$ \\
$\stackrel{0}{0}$ \\
\end{tabular} & $\begin{array}{l}\bar{\delta} \\
\bar{v}\end{array}$ & $\begin{array}{l}\stackrel{\infty}{\infty} \\
\stackrel{N}{N}\end{array}$ \\
\hline & $\infty$ & $\begin{array}{l}\text { 로 } \\
\tilde{\tilde{m}}\end{array}$ & g & 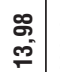 & 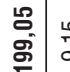 & 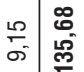 & $\begin{array}{l}28 \\
0 \\
00\end{array}$ & $\begin{array}{l}\bar{N} \\
\tilde{N}^{2}\end{array}$ & 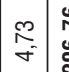 & \begin{tabular}{l|l}
2 & 5 \\
0 & 5 \\
0 & 5
\end{tabular} & 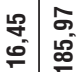 & $\bar{v}$ & 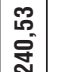 & $\begin{array}{l}\infty \\
\sim \\
\sim\end{array}$ & 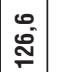 & $\bar{v}$ & 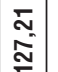 & $\bar{v}$ & $\tilde{f}$ \\
\hline 0 & की & $\left|\begin{array}{|l}0 \\
0 \\
0 \\
0\end{array}\right|$ & 足 & $\approx$ & $\begin{array}{l}E \\
\underline{a}\end{array}$ & 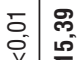 & $\begin{array}{l}\tilde{O} \\
\delta\end{array}$ & $\div$ & $\begin{array}{ll}8 \\
0 \\
0\end{array}$ & 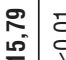 & \begin{tabular}{l|l}
$\bar{\delta}$ & 0 \\
0 & 0 \\
0
\end{tabular} & $\begin{array}{l}\delta \\
0 \\
0\end{array}$ & $\begin{array}{l}\mathscr{0} \\
\mathbf{S}^{\prime}\end{array}$ & $\begin{array}{l}\overline{0} \\
\overline{0}\end{array}$ & 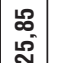 & $\overline{0}$ & $\begin{array}{l}\hat{0} \\
\tilde{m}\end{array}$ & $\begin{array}{l}\delta^{\prime} \\
\bar{y}\end{array}$ & $\underset{\text { so }}{\bar{n}}$ \\
\hline J & $\sum^{\circ}$ & 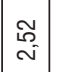 & 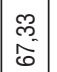 & $\bar{v}$ & 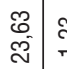 & 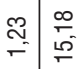 & 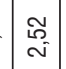 & $\begin{array}{c}\hat{\omega} \\
\omega^{0} \\
\omega^{2}\end{array}$ & $\bar{v}$ & 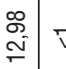 & $\bar{v} \mid \stackrel{\mathscr{R}}{\stackrel{\mathscr{N}}{N}}$ & $\bar{v}$ & $\mid \begin{array}{l}\infty \\
\stackrel{\infty}{\sim} \\
\stackrel{\sim}{\sim}\end{array}$ & $\begin{array}{l}\infty \\
\stackrel{\infty}{-}\end{array}$ & \begin{tabular}{|l|}
\multicolumn{2}{c}{} \\
$\sigma$ \\
$\sigma$ \\
\end{tabular} & $\bar{v}$ & $\frac{1}{\infty \infty^{\circ}}$ & $\bar{v}$ & $\frac{\pi}{8}$ \\
\hline$\sigma$ & $\sum$ & $\tau$ & 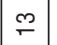 & $\bar{v}$ & م & $\bar{v} \simeq$ & $\bar{v}$ & $\simeq$ & $\bar{v} \mid c$ & $m$ & \begin{tabular}{l|l} 
& v
\end{tabular} & $\bar{v}$ & 으 & $\bar{v}$ & $\bar{v}$ & $\bar{v}$ & - & $\bar{v}$ & $\infty$ \\
\hline$\Leftrightarrow$ & - & $\frac{O}{v}$ & 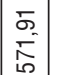 & $\frac{O}{v}$ & 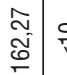 & 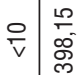 & $\stackrel{\circ}{\bar{v}}$ & 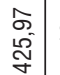 & $\stackrel{\circ}{\mathrm{v}}$ & 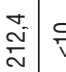 & \begin{tabular}{ll} 
& \multicolumn{1}{c}{} \\
$\bar{v}$ & $\delta$ \\
$\delta$
\end{tabular} & $\frac{O}{v}$ & - & $\frac{O}{v}$ & 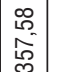 & 은 & $\begin{array}{c}\tilde{B} \\
\tilde{\Sigma} \\
\tilde{\sim}\end{array}$ & 은 & 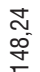 \\
\hline & ஸ் & I & ஜ & (8) & 名 & 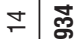 & 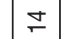 & $\bar{\sigma}$ & $\wedge$ & $\overline{\tilde{m}}$ & 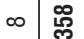 & ⿵人 & 웅 & $\bar{v}$ & 용 & $\bar{v}$ & ஜ & - & 适 \\
\hline 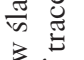 & $\mathcal{3}$ & $\mid \begin{array}{l}\tilde{\delta} \\
0 \\
0\end{array}$ & $\begin{array}{l}\hat{\theta} \\
\dot{\sigma}\end{array}$ & $\begin{array}{l}\overline{0} \\
\overline{0} \\
\overline{0}\end{array}$ & $\stackrel{\substack{N \\
N}}{ }$ & 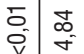 & $\begin{array}{l}\overline{0} \\
\bar{y}\end{array}$ & $\bar{\sigma}$ & $\begin{array}{l}\delta \\
\delta\end{array}$ & ấ & \begin{tabular}{l|l}
$\bar{\delta}$ & $\frac{m}{m}$ \\
$\bar{c}$ &
\end{tabular} & $\left|\begin{array}{l}\overline{0} \\
0 \\
\bar{v}\end{array}\right|$ & 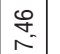 & $\begin{array}{l}\overline{0} \\
\overline{0} \\
\overline{0}\end{array}$ & $\stackrel{\infty}{\infty}$ & $\begin{array}{l}\overline{0} \\
\overline{0}\end{array}$ & $\frac{\infty}{i=}$ & $\begin{array}{l}\bar{\delta} \\
\overline{0} \\
\bar{y}\end{array}$ & $\underset{\infty}{\stackrel{\infty}{\infty}}$ \\
\hline a & ¿ & $\stackrel{\circ}{v}$ & $\frac{O}{v}$ & $\stackrel{\circ}{v}$ & 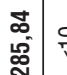 & 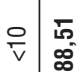 & $\frac{\circ}{\mathrm{v}}$ & $\frac{O}{v}$ & $\frac{O}{v}$ & $\stackrel{\circ}{v}$ & 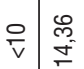 & $\frac{O}{v}$ & $\stackrel{\circ}{v}$ & $\stackrel{\circ}{v}$ & $\stackrel{\circ}{v}$ & $\stackrel{\circ}{v}$ & $\stackrel{\circ}{v}$ & $\frac{O}{v}$ & $\stackrel{\circ}{v}$ \\
\hline g & $\grave{\bar{\nu}}$ & ন & $\begin{array}{l}\mathscr{a} \\
\stackrel{2}{\infty}\end{array}$ & $\begin{array}{l}\stackrel{10}{\tilde{N}} \\
\stackrel{\mathrm{N}}{\mathrm{N}}\end{array}$ & $\begin{array}{l}\mathscr{a} \\
\dot{b} \\
\dot{0}\end{array}$ & 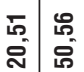 & $\begin{array}{l}\mathscr{8} \\
\mathbb{8} \\
\mathbb{e}\end{array}$ & $\begin{array}{c}\text { I } \\
\text { \&্ }\end{array}$ & $\begin{array}{l}\bar{\sigma} \\
\dot{N}\end{array}$ & 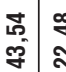 & 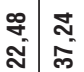 & $\mid$\begin{tabular}{l|} 
\pm \\
$\tilde{N}$ \\
$\tilde{N}$
\end{tabular} & $\begin{array}{c}\bar{\sigma} \\
\infty \\
q\end{array}$ & $\begin{array}{l}\text { ̊. } \\
\text { నิ่ }\end{array}$ & $\begin{array}{l}\frac{\sigma}{5} \\
\frac{m}{\infty}\end{array}$ & $\begin{array}{l}\widetilde{E} \\
\stackrel{-}{T}\end{array}$ & $\begin{array}{l}\Sigma \\
\bar{m} \\
\tilde{m}\end{array}$ & \begin{tabular}{l}
0 \\
\multirow{2}{*}{} \\
$\underline{n}$
\end{tabular} & $\begin{array}{c}\stackrel{\infty}{\sigma} \\
\frac{\pi}{\sigma}\end{array}$ \\
\hline & $\infty$ & $\stackrel{m}{\sim}$ & กิ & L & $\hat{m}$ & $\bar{v} \mid \ddot{m}$ & $\nabla$ & $\hat{m}$ & $\bar{v} \mid c$ & ৪) & $\bar{v} \bar{N}$ & $\bar{v}$ & $\approx$ & $\bar{v}$ & $\stackrel{2}{\circ}$ & $\bar{v}$ & $\approx$ & $\approx$ & \& \\
\hline & \& & $\bar{v}$ & ल & $\bar{v}$ & 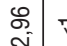 & \begin{tabular}{l|l}
$\bar{v}$ & $\bar{\sigma}$ \\
\end{tabular} & $\bar{v}$ & $\begin{array}{l}\infty \\
\stackrel{\infty}{\infty}\end{array}$ & $\bar{v}: z$ & $\hat{\sim}$ & \begin{tabular}{l|l}
$\bar{v}$ & $\stackrel{\infty}{=}$
\end{tabular} & $\bar{v}$ & $\begin{array}{l}\infty \\
\infty \\
\infty \\
\infty\end{array}$ & $\bar{v}$ & $\hat{\tilde{\omega}}$ & $\bar{v}$ & $\underset{\sim}{\tilde{\sigma}}$ & $\bar{v}$ & 吕 \\
\hline & $\varangle$ & $\nabla$ & ळ & $F$ & : & $F$ 웅 & 0 & 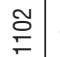 & $\sigma \mid$ & $\widetilde{\widetilde{N}}$ & $=$ ஜ & ஓ్ల & $\stackrel{\circ}{\stackrel{⿰}{+}}$ & $\bar{v}$ & ณ & $\sim$ & $\stackrel{\cong}{\simeq}$ & m & $\stackrel{\infty}{\rightleftharpoons}$ \\
\hline $\bar{z}$ & 운 & $\bar{v}$ & $\begin{array}{l}\mathscr{2} \\
\text { ల్ల }\end{array}$ & $\bar{v}$ & $\bar{v} \mid \bar{v}$ & $\bar{v} \mid \frac{\nabla}{i s}$ & $\bar{v}$ & $\begin{array}{l}\bar{z} \\
\stackrel{\sim}{N}\end{array}$ & $\bar{v}$ & \begin{tabular}{c|c}
$\bar{s}$ \\
$\underset{\omega}{0}$ & $\nabla$
\end{tabular} & \begin{tabular}{l|l}
$\bar{v}$ & $m$ \\
$\sigma^{-}$
\end{tabular} & $\bar{v}$ & $\bar{v}$ & $\bar{v}$ & $\bar{v}$ & $\bar{v}$ & $\bar{v}$ & $\bar{v}$ & $ㅇ ㅡ ㄷ$ \\
\hline$\Xi$ & 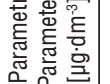 & 高 & 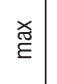 & 愛 & \begin{tabular}{l|l}
$\stackrel{x}{E}$ & :
\end{tabular} & 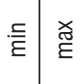 & 高 & $\stackrel{\underset{c}{g}}{E}$ & 高 & 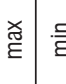 & 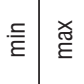 & 䧇 & $\stackrel{\underset{E}{E}}{E}$ & 高 & $\stackrel{\times}{E}$ & 愛 & $\stackrel{\underset{\varpi}{E}}{\stackrel{x}{E}}$ & 高 & 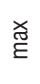 \\
\hline & 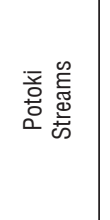 & 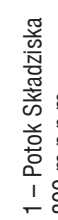 & 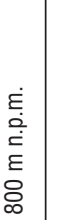 & $\begin{array}{l}\frac{0}{2} \\
\overline{2} \\
0 \\
0 \\
0 \\
0 \\
1 \\
\sim \\
\sim\end{array}$ & & 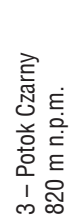 & $\frac{5}{5}$ & E & 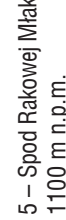 & & 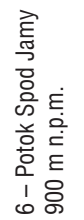 & & & 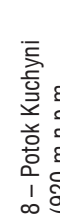 & & 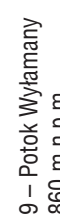 & $\begin{array}{l}\text { غ. } \\
\dot{\dot{\alpha}} \\
\dot{\dot{E}}\end{array}$ & 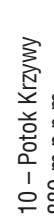 & $\begin{array}{c}\dot{\varepsilon} \\
\stackrel{\dot{\varepsilon}}{\dot{E}} \\
\underline{E}\end{array}$ \\
\hline
\end{tabular}




\begin{tabular}{|c|c|c|c|c|c|c|c|c|}
\hline 3 & $\mid$\begin{tabular}{l|}
$\overline{0}$ \\
0 \\
$\overline{0}$
\end{tabular} & $\underset{\Sigma}{\bar{N}}$ & $\begin{array}{l}\bar{\delta} \\
\bar{v} \\
\bar{v}\end{array}$ & $\begin{array}{l}\dot{J} \\
\mathrm{~m}^{-}\end{array}$ & \begin{tabular}{l|l}
$\delta$ & $e$ \\
$\bar{v}$ &
\end{tabular} & \begin{tabular}{l|l}
0 & $\bar{c}$ \\
$\sigma^{-}$ & $\bar{c}$
\end{tabular} & 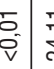 & \\
\hline$\supset$ & $\bar{v}$ & $\begin{array}{l}\stackrel{g}{F} \\
\stackrel{F}{F}\end{array}$ & $\bar{v}$ & 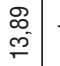 & $\bar{v} \mid$ & $\begin{array}{l}\infty \\
F \\
F\end{array}$ & $\bar{v}$ & \\
\hline$F$ & $\bar{v}$ & 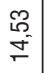 & $\bar{v}$ & $\begin{array}{l}8 \\
\bar{v} \\
\bar{v}\end{array}$ & $\bar{v}$ & $\begin{array}{c}\frac{m}{m} \\
\frac{m}{m} \\
\end{array}$ & $\bar{v}$ & \\
\hline $\bar{c}$ & 守 & $\stackrel{0}{ }$ & $\mp$ & 음 & $\stackrel{\infty}{\infty}$ & $\infty$ & $\infty \quad 7$ & \\
\hline ஸे & $\begin{array}{l}\bar{\delta} \\
\bar{\delta} \\
\bar{\delta}\end{array}$ & $\begin{array}{l}\stackrel{8}{\circ} \\
\stackrel{0}{0} \\
\stackrel{0}{0}\end{array}$ & $\begin{array}{l}\bar{\delta} \\
\bar{v} \\
\bar{v}\end{array}$ & $\stackrel{\leftrightarrow}{\stackrel{\circ}{\circ}}$ & \begin{tabular}{l|l}
$\bar{\delta}$ & $\overline{1}$ \\
$\bar{v}$ \\
$\bar{v}$
\end{tabular} & \begin{tabular}{c|c}
$\bar{c}$ & $\bar{E}$ \\
$\bar{\sigma}$ & $\bar{C}$ \\
\end{tabular} & 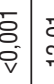 & \\
\hline ळ & \begin{tabular}{l|}
$\tilde{m}$ \\
$\tilde{j}$ \\
$\tilde{m}$
\end{tabular} & $\begin{array}{l}\bar{\infty} \\
\bar{\sigma}\end{array}$ & $\stackrel{\infty}{\sim}$ & 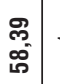 & $\bar{v}$ & 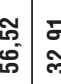 & $\begin{array}{ll}\tilde{\sigma} & \vdots \\
\text { ల్ల } & \vdots \\
\end{array}$ & \\
\hline की & \begin{tabular}{l|}
$\infty$ \\
0 \\
0
\end{tabular} & 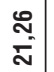 & $\begin{array}{l}\overline{0} \\
\bar{v}\end{array}$ & \begin{tabular}{l|}
$\frac{R}{m}$ \\
$m^{-1}$
\end{tabular} & $\begin{array}{ll}\delta & \alpha \\
0 & \\
v & \end{array}$ & 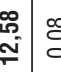 & $\begin{array}{lll}\infty & 1 \\
0 & 1 & \end{array}$ & \\
\hline$\stackrel{\circ}{\Sigma}$ & \begin{tabular}{|c|}
$\bar{\sigma}$ \\
$\omega^{\circ}$
\end{tabular} & $\begin{array}{l}\hat{0} \\
\hat{f}\end{array}$ & $\stackrel{\infty}{\mp}$ & $\begin{array}{l}\bar{c} \\
\stackrel{-}{c}\end{array}$ & $\bar{v}$ & 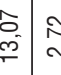 & 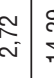 & \\
\hline$\sum$ & $\bar{v}$ & $\sigma$ & $\bar{v}$ & - & $\bar{v}$ & $\nabla \mid \nabla$ & $\bar{v}$ & \\
\hline- & $\frac{O}{v}$ & $\begin{array}{l}\hat{\Delta} \\
\text { సิ }\end{array}$ & $\stackrel{\circ}{v}$ & 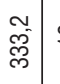 & 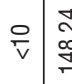 & 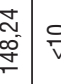 & 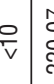 & \\
\hline ळ & $\sim$ & ஜ్ఞ & - & F & ๓ & প্ল্ণ & $\sim$ & \\
\hline \% & $\begin{array}{l}\overline{0} \\
\overline{0} \\
\bar{v}\end{array}$ & $\begin{array}{l}\tilde{N} \\
\bar{m}\end{array}$ & $\begin{array}{l}\overline{0} \\
\bar{v} \\
\bar{v}\end{array}$ & $\begin{array}{l}\hat{L} \\
\infty \\
\infty\end{array}$ & $\begin{array}{lll}\tilde{0} & \infty \\
\bar{v} & \end{array}$ & 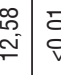 & $\begin{array}{c}\vdots \\
\overline{-} \\
\bar{v}\end{array}$ & \\
\hline $\bar{U}$ & $\frac{O}{v}$ & $\frac{O}{\mathrm{v}}$ & $\frac{0}{\mathrm{v}}$ & $\stackrel{\circ}{v}$ & $\stackrel{\circ}{v}$ & $\frac{O}{v} \stackrel{.}{v}$ & $\frac{0}{v}$ & \\
\hline$\overline{\grave{c}}$ & 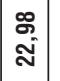 & $\frac{\cong}{m}$ & $\begin{array}{l}\mathscr{Q} \\
\tilde{5}\end{array}$ & $\begin{array}{l}\stackrel{2}{2} \\
\bar{m}\end{array}$ & $\begin{array}{l}\stackrel{8}{\circ} \\
\tilde{\sim}\end{array}$ & 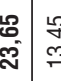 & 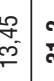 & \\
\hline$\infty$ & 0 & $\tilde{\sim}$ & $\sim$ & ஜ్ల & $\bar{v}$ & $\stackrel{m}{m}$ & $m:$ & \\
\hline 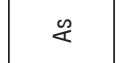 & $\bar{v}$ & $\begin{array}{l}0 \\
\stackrel{L}{\circ} \\
\omega^{\circ}\end{array}$ & $\bar{v}$ & $\stackrel{े}{m^{\prime}}$ & $\bar{v}$ & \begin{tabular}{l|l}
$\stackrel{8}{e^{\prime}}$ & $\nabla$
\end{tabular} & $\bar{v}$ & \\
\hline $\bar{\varangle}$ & $\infty$ & ธ్ & - & 尺 & 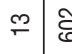 & 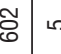 & ه & \\
\hline 우 & $\bar{v}$ & $\bar{v}$ & $\bar{v}$ & $\bar{v}$ & $\bar{v}$ & $\bar{v} \mid \bar{v}$ & $\bar{v}$ & \\
\hline 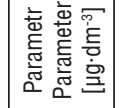 & 高 & ֻ & 呟 & $\stackrel{\text { đ }}{E}$ & 言 & 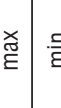 & E. & 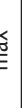 \\
\hline 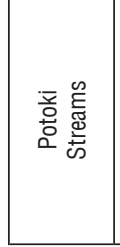 & 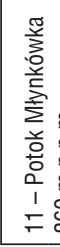 & & 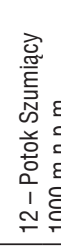 & & 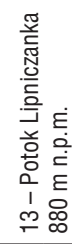 & & 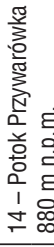 & \\
\hline
\end{tabular}


Wystąpiła tutaj wyraźna korelacja podwyższonych wartość $\mathrm{Al}$ z podwyższonymi wartościami Fe, co jest związane z naturalnym procesem geochemicznym buforowania kwaśnych opadów przez glinokrzemiany (ryc. 8).

W wodach 13 potoków przekroczone zostało dopuszczalne stężenie antymonu (Sb) dla wód przeznaczonych do spożycia przez ludzi (Rozp. Min. Zdrowia z 2015 r.). Podwyższone stężenia Sb w wodach występowały jesienią i zimą. Przekroczenia stężenia $\mathrm{Sb}$ (przy dopuszczalnej $5 \mu \mathrm{g} \cdot \mathrm{dm}^{-3}$ ) objęły wody potoków: Składziska, Sylec, Czarny, Kiczorka, Spod Rakowej Młaki, Spod Jamy, Jamy, Kuchyni, Wyłamany, Krzywy, Młynkówka, Lipniczanka oraz Przywarówka. W październiku zanotowano przekroczenia dopuszczalnych stężeń w wodach potoków: Sylec (najwyższa wartość wyniosła 12,11 $\mu \mathrm{g} \cdot \mathrm{dm}^{-3}$ ), Czarny 15,39 $\mu \mathrm{g} \cdot \mathrm{dm}^{-3}$, Kiczorka 20,16 $\mu \mathrm{g} \cdot \mathrm{dm}^{-3}$, Spod Rakowej Młaki 15,79 $\mu \mathrm{g} \cdot \mathrm{dm}^{-3}$, Spod Jamy 6,6 $\mu \mathrm{g} \cdot \mathrm{dm}^{-3}$, Jamy 10,06 $\mu \mathrm{g} \cdot \mathrm{dm}^{-3}$, Kuchyni 25,85 $\mathrm{g} \cdot \mathrm{dm}^{-3}$, Wyłamany 13,67 $\mathrm{\mu g} \cdot \mathrm{dm}^{-3}$, Krzywy 5,71 $\mu \mathrm{g} \cdot \mathrm{dm}^{-3}$, Młynkówka 21,26 $\mu \mathrm{g} \cdot \mathrm{dm}^{-3}$, Lipniczanka 12,58 $\mu \mathrm{g} \cdot \mathrm{dm}^{-3}$ oraz Przywarówka 4,77 $\mu \mathrm{g} \cdot \mathrm{dm}^{-3}$. W lutym zanotowano przekroczenie stężenia w wodzie potoku Składziska, najwyższa wartość wyniosła 21,83 $\mu \mathrm{g} \cdot \mathrm{dm}^{-3}$ (tab. 2, ryc. 7).

Dopuszczalne stężenie selenu (Se) dla wód przeznaczonych do spożycia przez ludzi (Rozp. Min. Zdrowia z 2015 r.) zostało przekroczone w wodach 14 potoków.

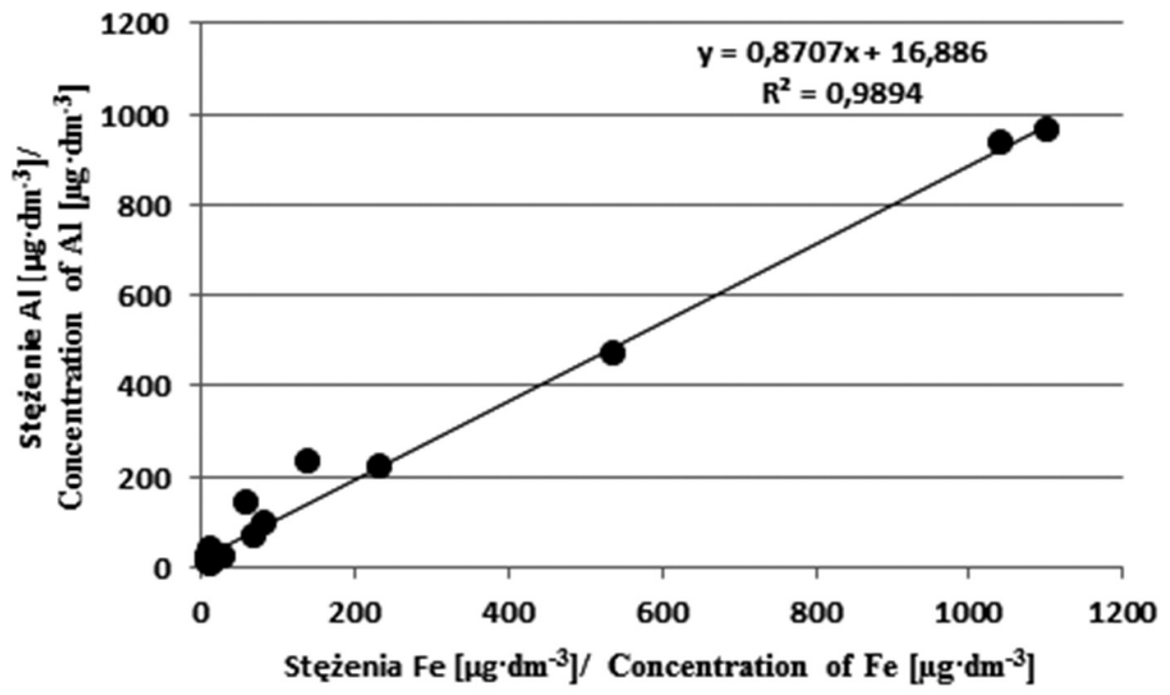

Rys. 8. Korelacja stężeń $\mathrm{Al}$ do $\mathrm{Fe}$ w wodach analizowanych potoków

Fig. 8. Correlation concentrations $\mathrm{Al}$ and $\mathrm{Fe}$ in the waters of the analyzed streams 
Podwyższone stężenia Se występowały latem, jesienią i wiosną. Przekroczenia stężenia Se (przy dopuszczalnym stężeniu $10 \mu \mathrm{g} \cdot \mathrm{dm}^{-3}$ ) objęły wody potoków: Składziska, Sylec, Czarny, Kiczorka, Spod Rakowej Młaki, Spod Jamy, Jamy, Kuchyni, Wyłamanym, Krzywy, Młynkówka, Lipniczanka oraz Przywarówka. W lipcu zanotowano przekroczenia dopuszczalnego stężenia w wodach potoków: Kiczorka (najwyższa wartość wyniosła 29,71 $\mu \mathrm{g} \cdot \mathrm{dm}^{-3}$ ), Jamy 240,53 $\mu \mathrm{g} \cdot \mathrm{dm}^{-3}$, Kuchyni $126,6 \mu \mathrm{g} \cdot \mathrm{dm}^{-3}$ oraz Krzywy 74,7 $\mu \mathrm{g} \cdot \mathrm{dm}^{-3}$. W październiku zanotowano przekroczenia w wodach potoków: Składziska (najwyższa wartość wyniosła $190,49 \mu \mathrm{g} \cdot \mathrm{dm}^{-3}$ ), Sylec 199,05 $\mu \mathrm{g} \cdot \mathrm{dm}^{-3}$, Czarny 135,68 $\mu \mathrm{g} \cdot \mathrm{dm}^{-3}$, Spod Rakowej Młaki 206,76 $\mu \mathrm{g} \cdot \mathrm{dm}^{-3}$,

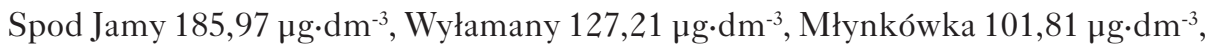
Lipniczanka 56,52 $\mu \mathrm{g} \cdot \mathrm{dm}^{-3}$ oraz Przywarówka $150,88 \mu \mathrm{g} \cdot \mathrm{dm}^{-3}$. W maju zanotowano przekroczenie w wodzie potoku Szumiącego, największa wartość wyniosła $58,39 \mu \mathrm{g} \cdot \mathrm{dm}^{-3}$ (tab. 2, ryc. 7).

\section{Dyskusja}

Budowa geologiczna obszaru badań z przewagą odpornego na wietrzenie i rozpuszczanie piaskowca magurskiego znacznie utrudnia wzbogacanie wód potoków w składniki mineralne, co odzwierciedla się w niskiej mineralizacji ich wód.

Proces rozcieńczania przez niskozmineralizowane wody opadów atmosferycznych uwidacznia się w zależności: im wyższe wartości sum opadów atmosferycznych, tym wyższe natężenie przepływu wody, a zarazem niższe stężenia jonów (Malata 2015). Świadczą o tym niższe (w porównaniu z sezonem jesiennym i zimowym) wartości jonów $\mathrm{Ca}, \mathrm{Mg}$ oraz $\mathrm{HCO}_{3}$ w porze wiosennej i letniej - związane z opadami deszczu i topnieniem pokrywy śnieżnej (ryc. 3) (Malata 2015).

Wysokie wartości jonów $\mathrm{Na}, \mathrm{K}, \mathrm{SO}_{4}, \mathrm{PO}_{4}$ wiosną w wodach potoków wskazują na wpływ opadów atmosferycznych oraz dostawę jonów z pokryw zwietrzelinowo-glebowych (Małecka 1991; Małecka i in. 2007; Kurzyca i in. 2009; Malata 2015;). Badania prowadzone na obszarze masywu Tatr przez m.in. przez Wolanin (2013) potwierdzają podaną zależność wpływu intensywności opadów atmosferycznych, na skład fizykochemiczny wód potoków. Wyraźne obniżenie pH wody (na przykładzie m.in. potoku Sylec od 7,4 w lipcu do 8,8 w październiku) w czasie wezbrania w lipcu świadczy o wpływie opadów atmosferycznych. By potwierdzić ten pogląd, wykonano badania fizykochemiczne wód opadowych z obszaru badań, wartości pH tych wód mieściły się w zakresie odczynu kwaśnego od 4,7 do 5,6. Wyniki te potwierdzają pogląd, że zanieczyszczenia pochodzące z opadów atmosferycznych powodują m.in. zakwaszanie wód powierzchniowych (Kownacki i in. 2006). Przekrojowe dane składu fizyko-chemiczne z rejonu masywu Babiej Góry zamieszczone zostały w opracowaniu Łajczaka (1998). Analizowane wody 
potoków oscylowały od słabo kwaśnych do słabo zasadowych. Średnie zakresy pH analizowanych wód mieściły się w przedziale 6,8-8,9 podanym przez Pasternaka (1983) dla wód Babiej Góry.

Analiza zmienności czasowej stężeń pierwiastków i związków wskazuje na wpływ klimatycznych pór roku i okresu wegetacji roślin na skład chemiczny wód potoków (Malata 2015). Duże znaczenie dla składu fizyko-chemicznego wód analizowanych potoków miało wystąpienie w 2014 i 2015 r. suchego i ciepłego lata oraz łagodnej zimy. Niższa mineralizacja wód latem i wiosną może być związana z wpływem bujnie rozwijającej się roślinności. Można przypuszczać, że wynika to z większej asymilacji azotanów na obszarach z miąższymi glebami brunatnymi i bujną roślinnością w pełni okresu wegetacyjnego (Baron i in. 1994). Niższe wartości przepływu wód latem spowodowane są brakiem obfitych opadów atmosferycznych. Niższe przepływy wód potoków spowodowane są m.in. przez pobieranie wody przez roślinność, glebę oraz parowanie. Niższe wartości PEW mogą być związane z występowaniem roztopów wiosennych, co powoduje zwiększenie wydajności przepływu potoków, a tym samym większe rozcieńczanie ich wód przez słabo zmineralizowane wody roztopowe.

Wysokie stężenia glinu i żelaza prawdopodobnie są wynikiem naturalnych procesów geochemicznych oraz wpływu odczynu wody. Wyższe stężenia Al i Fe występują zazwyczaj w wodach o niskim pH, co potwierdziły przeprowadzone badania. Charakterystycznym procesem geochemicznym występującym na obszarze masywu Babiej Góry, który ma wpływ na skład chemiczny jest buforowanie kwaśnych opadów przez glinokrzemiany (Malata, Motyka 2015). Przekroczenia wartości granicznych dla wód czystych w stosunku do Fe mogły być spowodowane również dostaniem się do wody pyłów ze spalania węgla opałowego (Kabata-Pendias, Pendias 1999; Witczak i in. 2013).

Niepokojące są przekroczenia dopuszczalnych wartości Ag, As, Br, Cr, Sb oraz Se (tab. 2, ryc. 7). Przekroczenia stężeń tych pierwiastków ciężkich w wodzie mogą być spowodowane dopływem zanieczyszczeń powstałych w wyniku działalności antropogenicznej. Wysokie stężenia Ag, Br, Sb, Se wystąpiły w wodach potoków: Składziska, Kiczorka, Spod Rakowej Młaki. W wodach potoków Sylec i Czarny zostały przekroczone stężenia $\mathrm{Br}, \mathrm{Cr}, \mathrm{Sb}$, Se. Wysokie stężenie Br wystąpiło również w wodzie potoku Szumiącego. Przekroczenia dopuszczalnych stężeń dla Br, Sb, Se pojawiły się w wodach potoków: Spod Jamy, Kuchyni, Wyłamany, Krzywy, Młynkówka, Lipnicznka i Przywarówka. W wodzie potoku Jamy zanotowano wysokie wartości stężeń As, $\mathrm{Br}$, Sb oraz Se.

Wysokim stężeniom srebra (Ag) sprzyja kwaśny oraz słabo zasadowy odczyn wody, który umożliwia przemieszczaniu się tego pierwiastka na duże odległości (Kabata-Pendias, Pendias 1999). Wyższe stężenia Ag w wodzie może być spowodowane dostaniem się do wody ścieków komunalnych, pyłów ze spalania węgla opa- 
łowego, pyłów ze spalania śmieci oraz oleju napędowego i benzyn (Kabata-Pendias, Pendias 1999; Witczak i in. 2013).

Migracji arsenu (As) także sprzyja kwaśny odczyn wody, które ułatwia przemieszczanie się tego pierwiastka na duże odległości (Kabata-Pendias, Pendias 1999). Wyższe stężenie As w wodzie może być spowodowane dostawą do wody: ścieków komunalnych, pyłów ze spalania węgla opałowego, oraz oleju napędowego i benzyn oraz z działalności rolniczej aktualnej oraz z przeszłości (Kabata-Pendias, Pendias 1999; Witczak i in. 2013). W pobliskich wioskach występują pola uprawne oraz przydomowe ogrody. W przeszłości popularne były środki ochrony roślin na bazie arsenu, które zostały wycofane z produkcji. Ich wieloletnie stosowanie uwidacznia się jednak w wynikach badań w całej Polsce (Kabata-Pendias, Pendias 1999).

Wysokie stężenia bromu (Br) w wodzie na tym obszarze mogą być wynikiem naturalnych procesów wietrzenia skał osadowych budujących obszar lub działalnością człowieka. Antropogenicznie Br dostaje się do wody wraz z pyłami ze spalania węgla opałowego, oleju napędowego i benzyn wysokooktanowych oraz z działalnością rolniczą (Kabata-Pendias, Pendias 1999).

Z kolei wysokie stężenia chromu (Cr) w wodzie mogą być spowodowane dostaniem się do wody odpadów lakierów antykorozyjnych stosowanych w warsztatach samochodowych, preparatów grzybobójczych do drewna stosowanych w tartakach oraz poprzez działalność rolniczą, w tym: użyźnianie gleb, wapniowanie czy nawozy na bazie chromu (Kabata-Pendias, Pendias, 1999; Witczak i in. 2013).

Wysokie stężenia selenu (Se) mogą wynikiem przedostawania się tego pierwiastka do wody wraz z pyłami ze spalania węgla opałowego, ściekami i odpadami komunalnymi oraz wraz z działalnością rolniczą (nawozy fosforanowe). Typowe źródła $\mathrm{Sb}$ w wodzie to: pyły ze spalania węgla opałowego oraz ścieki i odpady komunalne (Kabata-Pendias, Pendias 1999; Witczak i in. 2013).

\section{Podsumowanie i wnioski}

Wpływ negatywnego oddziaływania człowieka na wody analizowanych potoków określono na badanym obszarze jako wyraźny. Negatywny wpływ na jakość fizykochemiczną wód potoków mają rolnictwo oraz działalność małych firm (tartak i warsztaty mechaniczne w pobliskich wioskach). Środki ochrony roślin na bazie m.in. As, Br, Cr i Se, które poprzez spływ podpowierzchniowy oraz infiltrację dostają się do gleby podwyższają stężenia metali ciężkich w wodach. Działanie nowoczesnej oczyszczalni ścieków w rejonie schroniska Markowe Szczawiny skutecznie zapobiega przedostawaniu się tych substancji do cieków powierzchniowych. Ciągle aktywne pozostają jednak inne źródła pochodzenia zanieczyszczeń: dopływy ścieków, odpady komunale i pyły ze spalania węgla opałowego oraz pyły przemysłowe przenoszone z dalej położonych obszarów. 
Opracowanie zostało zrealizowane w ramach grantu dziekańskiego - umowa nr 15.11.140.633 oraz badań statutowych Katedry Hydrogeologii i Geologii Inżynierskiej - umowa nr 11.11.140.797

\section{Literatura}

Alexandrowicz S.W., 2004, Zarys budowy geologicznej Babiej Góry, [w:] W. Wołoszyn, A. Jaworski, J. Szwagrzyk (red.), Babiogórski Park Narodowy. Monografia przyrodnicza, Wydawnictwo i Drukarnia Towarzystwa Słowaków w Polsce, Kraków, 87-107.

Baron J.S., Ojima D.S., Holland E.A., Parton W.J., 1994, Analysis of nitrogen saturation potential in Rocky Mountain tundra and forest: Implication for aquatic systems, Biogeochemistry, 27, 61-82.

Chełmicki W., 2001, Woda. Zasoby, degradacja i ochrona, Wydawnictwo Naukowe PWN, Warszawa.

Franczak P., Hudyka M., Buczek K., Górnik M., 2015, Zró́nicowanie præestræenne $i$ zmiennoś odptywu w zlewniach flisะowych na obszarะe Masywu Babiej Góry, Annales Universitatis Mariae Curie-Skłodowska, 70, 1, 95-116.

Holeksa J., Szwagrzyk J., 2002, Szata roślinna, [w:] D. Ptaszycka-Jackowska (red.), Światy Babiej Góry, Grafikon, Zawoja, 41-95.

http://www.freemeteo.pl (1.12.2015).

Kabata-Pendias A., Pendias H., 1999, Biogeochemia pierwiastków Sladowych, Wydawnictwo Naukowe PWN, Warszawa.

Kleczkowski A.S., 1990, Mapa obsæarów głównych «biorników wód podziemnych (GZWP) w Polsce wymagajacych szczególnej ochrony, skala 1: 500 000, Wyd. Katedra Hydrogeologii i Geologii Inżynierskiej AGH, Kraków.

Kondracki J., 2002, Geografia regionalna Polski, Wydawnictwo Naukowe PWN, Warszawa.

Kownacki A., Dumnicka E., Kwadrans J., Galas J., Ollik M., 2006, Benthic communities in relation to environmental factors in small high mountain pounds threatened by air pollutants, Boreal Environment Research, 11, 481-492.

Książkiewicz M., 1971, Szczegótowe mapy geologiczne Polski w skali 150 000, ark. Zawoja (1031) wraz z objaśnieniami, PIG, Warszawa.

Kurzyca I., Choiński A., Koniecki A., Siepak J., 2009, Water ecosystems affected by human impact within the protected area of the Tatra National Park (Poland), Oceanological and Hydrobiological Studies, 38 (3), 77-86.

Łajczak A., 1983, Wody podziemne, [w:] K. Zabierzowski (red.), Park Narodowy na Babiej Górze. Przyroda i čtowiek, Zakład Ochrony Przyrody i Zasobów Narodowych PAN-PWN, Warszawa-Kraków, 79-94.

Łajczak A., 1998, Charakterystyka hydrografic:na, sasoby wodne, sagrożenie wód $i$ wykonanie szczegótowej mapy hydrograficznej Babiogórskiego Parku Narodowego, [w:] A. Łajczak (red.), Plan ochrony Babiogórskiego Parku Narodowego, Zawoja (maszynopis). 
Łajczak A., 2004., Wody Babiej Góry, [w:] W. Wołoszyn, A. Jaworski, J. Szwagrzyk (red.), Babiogórski Park Narodowy. Monografia przyrodnicza, Komisja Ochrony Przyrody PAN, Kraków, 153-177.

Macioszczyk A., 1987, Hydrogeochemia, Wydawnictwa Geologiczne, Warszawa.

Malata M., 2014, Wybrane właściwości fizyczno-chemiczne potoków Babiogórskiego Parku Narodowego, Słupskie Prace Geograficzne, 11, 65-76.

Malata M., 2015, Sezonowa zmienność fizyko-chemiczna źródet Babiogórskiego Parku Narodowego, Przegląd Naukowy. Inżynieria i Kształtowanie Środowiska, 67, 26-39.

Malata M., Motyka J., 2015, Chemizm wód źródet w zlewni Markowego Potoku. Babiogórski Park Narodowy, Przegląd Geologiczny, 63, 247-255.

Małecka D., 1991, Opady atmosferyczne jako ważny czynnik ksstattująy chemizm wód podziemnych, Przegląd Geologiczny, 1, 14-19.

Małecka D., Chowaniec J., Małecki J.J., 2007, Region górnej Wisty, [w:] B. Paczyński, A. Sadurski (red.), Hydrogeologia regionalna Polski, Tom 1. Wody stodkie, PIG, Warszawa, 108-158.

Miechówka A., Niemyska- Łukaszuk J., 2004, Gleby Babiej Góry, [w:] W. Wołoszyn, A. Jaworski, J. Szwagrzyk (red.), Babiogórski Park Narodowy. Monografia przyrodnicza, Komisja Ochrony Przyrody PAN, Kraków, 197-212.

Obrębska-Starkel B. ,1963, Klimat Babiej Góry, [w:] W. Szafer (red.), Babiogórski Park Narodowy, Wydawnictwo Naukowe PWN, Kraków, 45-69.

Paczyński B., 1995, Atlas hydrogeologiczny Polski w skali 1: 500 000. Systemy zwyktych wód podziemnych, Zasoby, jakość i ochrona zwyktych wód podziemnych, PIG, Warszawa.

Paczyński B., Sadurski A., 2007, Hydrogeologia regionalna Polski, T. 1. Wody stodkie, PIG, Warszawa.

Postawa A., 2005, Zarys aktualnych warunków hydrogeologicænych Babiogórskiego Parku Narodowego, [w:] XII Współczesne Problemy Hydrogeologii, Wydawnictwo Naukowe PWN, Toruń, 839-841.

Pasternak K., 1983, Wody powierzchniowe, [w:] K. Zabierzowski (red.), Park Narodowy na Babiej Górze. Przyroda i čtowiek, Zakład Ochrony Przyrody i Zasobów Narodowych PAN, Warszawa-Kraków, 63-78.

Rozporządzenie Ministra Zdrowia z dnia 13 listopada 2015r. w sprawie jakości wody przeznaczonej do spożycia przez ludzi (Dz.U. 2015 poz. 1989).

Siwek J., Siwek J.P., Żelazny M., 2009, Wpływ ścieków zrzucanych ze schronisk tatrzańskich na chemizm wód rzecznych TPN, [w:] R. Bogdanowicz, J. Fac-Beneda (red.), Zasoby i ochrona wód. Obieg wody i materii w zlewniach rzecznych, Fundacja Rozwoju Uniwersytetu Gdańskiego, Gdańsk, 468-475.

Watycha L., 1977, Szczegótowe mapy geologiczne Polski w skali 1: 50 000, ark. Jabtonka (1047) wraz z objaśnieniami, PIG, Warszawa.

Witczak S., Kania J., Kmiecik E., 2013, Katalog wybranych fizycznych i chemicznych wskazników zanieczyszczeń wód podziemnych i metod ich oznaczania, IOŚ, Warszawa. 
Wolanin A., 2013, Wtaściwości fizykochemiczne wody potoków tatrzańskich wo okresie kwiecień-listopad 2011 roku, Prace Geograficzne, 133 (1), 49-60 doi: 10.4467/20833113PG.13.010.1100

Wójcik A., Rączkowski A., Mrozek T., Nescieruk P., Marciniec P., Zimnal Z., 2010, Mapa geologiczno-turystyczna Babiogórskiego Parku Narodowego 1: 13 WPIG, Warszawa.

Żelazny M., Wolanin A., Płaczkowska E ., 2009, Przestrzenne zróżnicowanie i sezonowe zmiany cech fizyczno-chemicznych wód potoków Kościeliskiego i Chochotowskiego w Tatrach Zachodnich, [w:] R. Bogdanowicz, J. Fac-Beneda (red.), Zasoby i ochrona wód. Obieg wody i materii w zlewniach ræecznych, Fundacja Rozwoju Uniwersytetu Gdańskiego, 461-467.

Żelazny M., Wolanin A., Płaczkowska E., 2013, Hypsometric factors for differences in chemical composition of spring waters of the Tatra National Park, Polish Journal of Environmental Studies, 22 (1), 289-299.

\author{
Matgorzata Malata \\ AGH Akademia Górniczo-Hutnicza \\ Wydziat Geologii Geofizyki i Ochrony Środowiska \\ al. Mickiewicะa 30, 30-059 Kraków \\ malatamalgorzata@wp.pl \\ Jacek Motyka \\ AGH Akademia Górniczo-Hutnicza \\ Wydziat Geologii Geofizyki i Ochrony Środowiska \\ al. Mickiewicza 30, 30-059 Kraków \\ motyka@agh.edu.pl \\ Adam Postawa \\ AGH Akademia Górniczo-Hutnicæa \\ Wydziat Geologii Geofizyki i Ochrony Środowiska \\ al. Mickiewicะa 30, 30-059 Kraków \\ postawa@agh.edu.pl
}

